

\section{Summary of the}
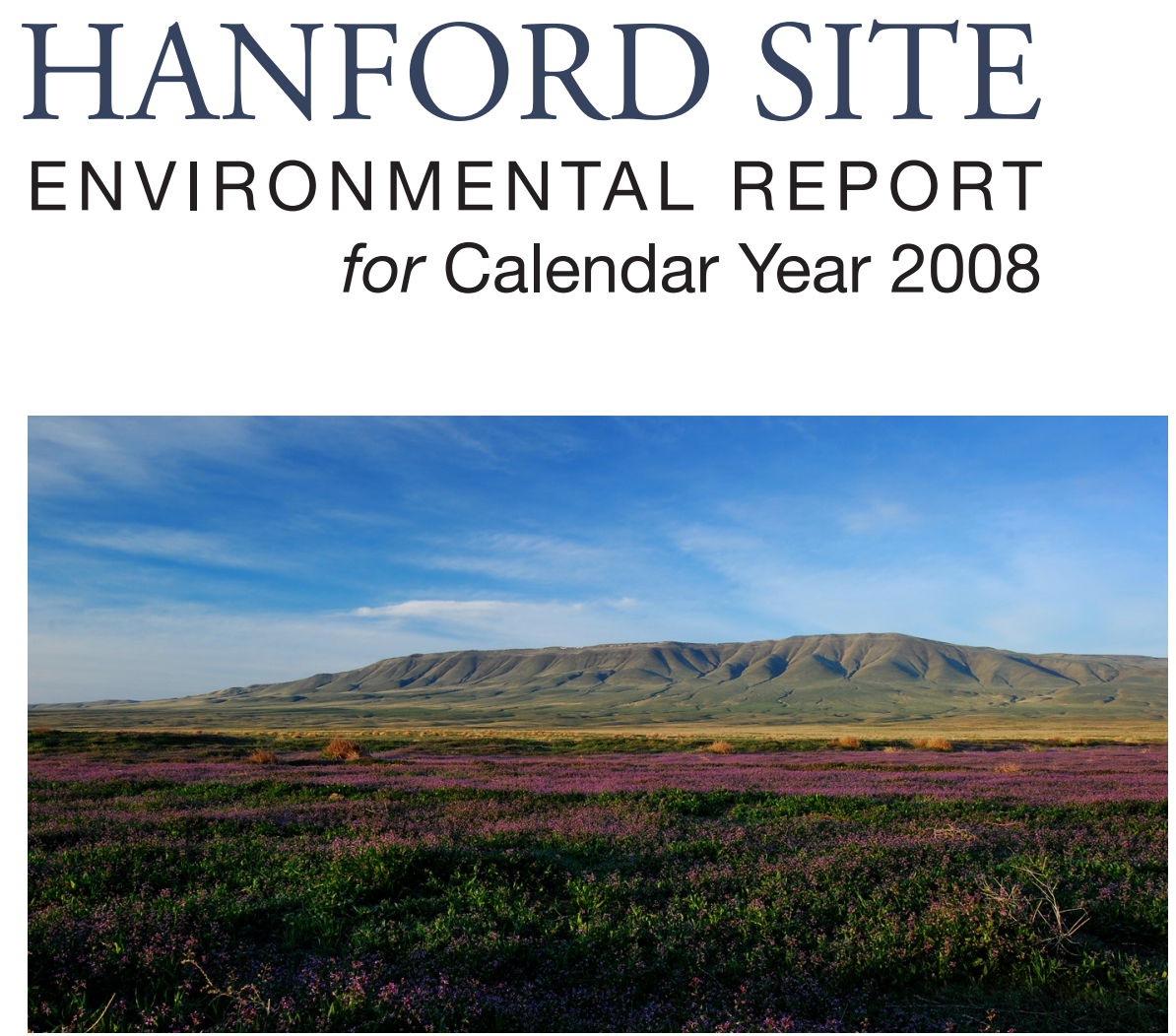

\section{EDITORS}

JP DUNCAN

TM POSTON

\section{RL DIRKES}

\section{SEPTEMBER 2009}

Prepared for the U.S. Department of Energy by Pacific Northwest National Laboratory under contract DE-AC05-76RL01830, with contributions from Bechtel National, Inc.; CH2M HILL Plateau Remediation Company; Fluor Hanford, Inc. and its subcontractors; Washington Closure Hanford, LLC; and Washington River Protection Solutions, LLC

Pacific Northwest National Laboratory Richland, Washington 


\title{
DISCLAIMER
}

This report was prepared as an account of work sponsored by an agency of the United States Government. Reference herein to any specific commercial product, process, or service by trade name, trademark, manufacturer, or otherwise does not necessarily constitute or imply its endorsement, recommendation, or favoring by the United States Government or any agency thereof, or Battelle Memorial Institute.

\section{COVER}

The cover photo shows swards of exotic purple mustard (Chorispora tenella) and the remains of last year's Russian thistle (Salsola tragus) that dominate swales in the Cold Creek Valley burned by past wildfires. At higher elevations on Rattlesnake Ridge, native perennial bunchgrassess persist after being burned and present green slopes during the spring and early summer. Photo is courtesy of S Butner, Pacific Northwest National Laboratory, Richland, Washington. The cover and layout designs are by SB Colson and document layout is by KR Neiderhiser, both of Pacific Northwest National Laboratory, Richland, Washington.

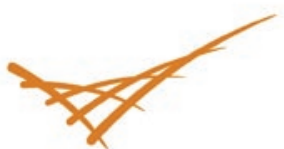

\section{Pacific Northwest}

\author{
NATIONAL LABORATORY
}

Proudly Operated by Battelle Since 1965 


\section{CONTENTS}

Introduction 1

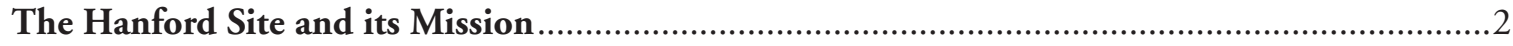

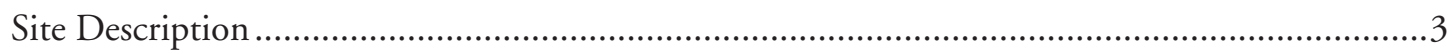

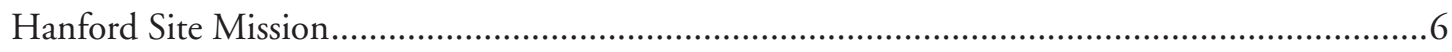

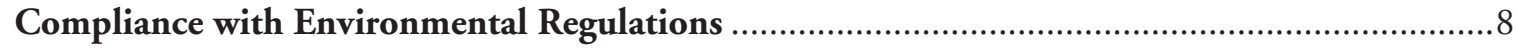

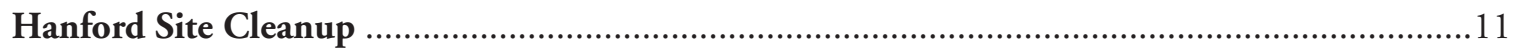

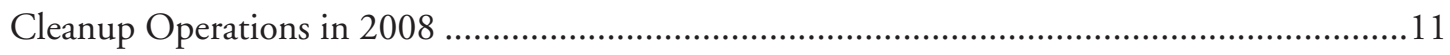

Facility Decommissioning and Deactivation Activities in 2008 ..............................................13

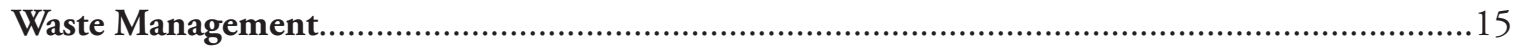

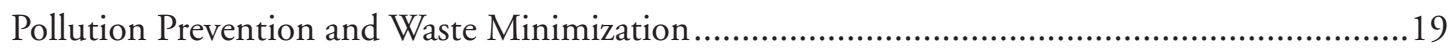

Environmental and Resource Protection Programs ..........................................................20

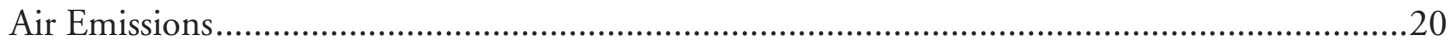

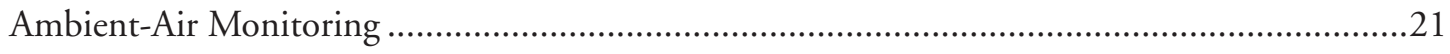

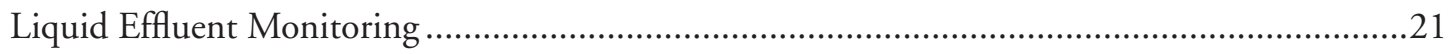

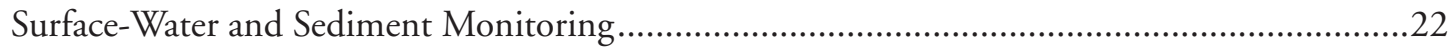

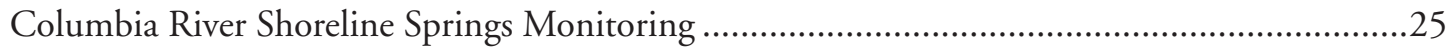

Radiological Monitoring of Hanford Site Drinking Water ....................................................26

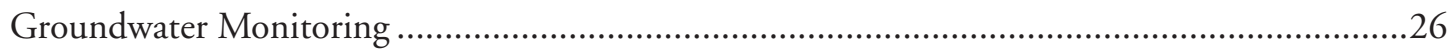

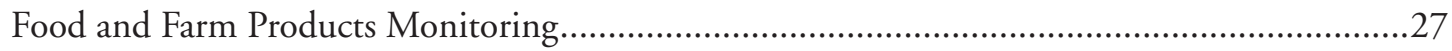

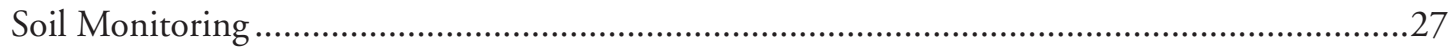




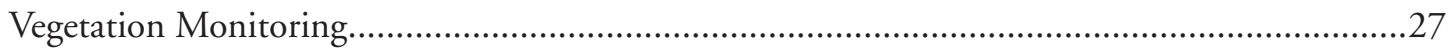

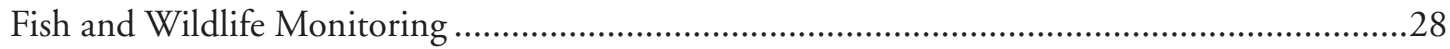

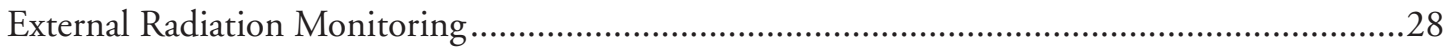

Potential Radiological Doses from 2008 Hanford Operations..................................................29

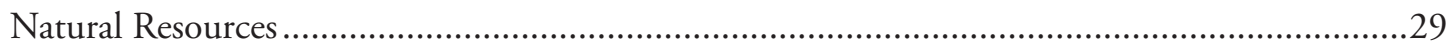

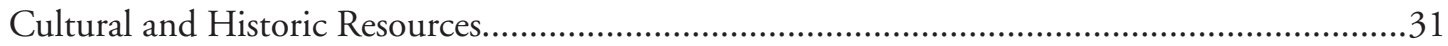

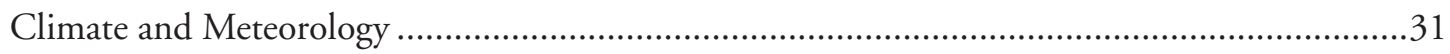

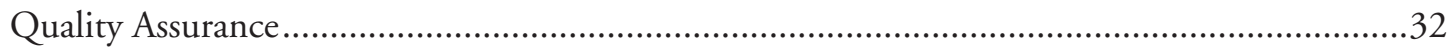




\section{INTRODUCTION}

This booklet summarizes the Hanford Site Environmental Report for Calendar Year 2008. The Hanford Site environmental report, published annually since 1959, includes information and summary data that provide an overview of activities at the U.S. Department of Energy's (DOE) Hanford Site.

Included in this booklet are brief descriptions of the Hanford Site and its mission, the status and results of cleanup and facility deactivation and decommissioning activities, environmental monitoring and surveillance programs and activities, and estimated radiological doses to the public and biota from 2008 Hanford Site activities. This booklet was written with a minimum of technical terminology. Readers interested in more detailed information can consult the 2008 Hanford Site environmental report or the technical documents cited and listed in that report. This booklet and the report are available online at http://hanford-site.pnl.gov/envreport/.
The White Bluffs are located on the Hanford Site along the eastern shore of the Columbia River in the Wahluke Unit of the Hanford Reach National Monument. Photo courtesy of Geoffrey McMichael. 


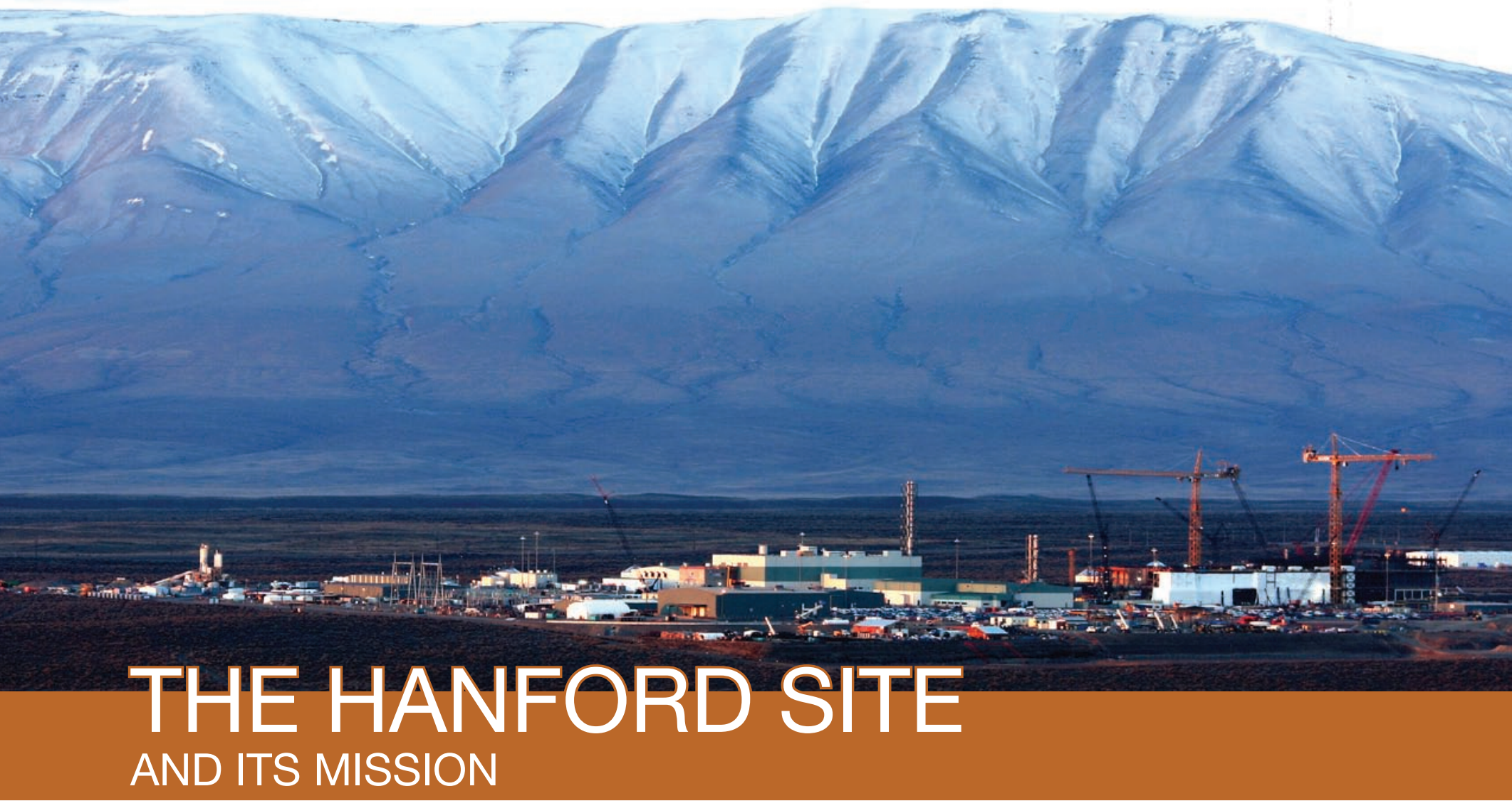

Rattlesnake Mountain, rising to 3,525 feet above sea level, provides a backdrop to construction of the Hanford Tank Waste Treatment and Immobilization Plant. Photo courtesy of Mike Guthrie.

The Hanford Site, the first nuclear production facility in the world, was established in 1943 to produce plutonium for national defense. The site was selected by the U.S. Army Corps of Engineers because of its remoteness and because it had abundant electrical power from Grand Coulee Dam, a functional railroad, clean water from the Columbia River, and available sand and gravel for construction. During the next 21 years, nine plutonium-production reactors were constructed by DOE on the Hanford Site, along with facilities to separate and purify the reactor products into required forms. One reactor operated beyond the early 1970s; all were decommissioned by the late 1980s.

In the late 1970s, the federal government constructed the Fast Flux Text Facility, a liquid-sodium-cooled nuclear reactor on the Hanford Site to test advanced nuclear fuels, materials, and components. This reactor operated until April 1992, and deactivation and decommissioning activities began in December 2001 and are nearly complete. 
Today, under the direction of DOE, the Hanford Site is engaged in the world's largest environmental remediation and cleanup project, collaborating with technical, regulatory, cultural, financial, and political groups and representatives.

Non-DOE operations and activities on Hanford Site leased land include commercial power production by Energy Northwest at the Columbia Generating Station and operation of a commercial low-level radioactive waste burial site by US Ecology Washington, Inc. The Laser Interferometer Gravitational-Wave Observatory (LIGO) is located west of the 400 Area and

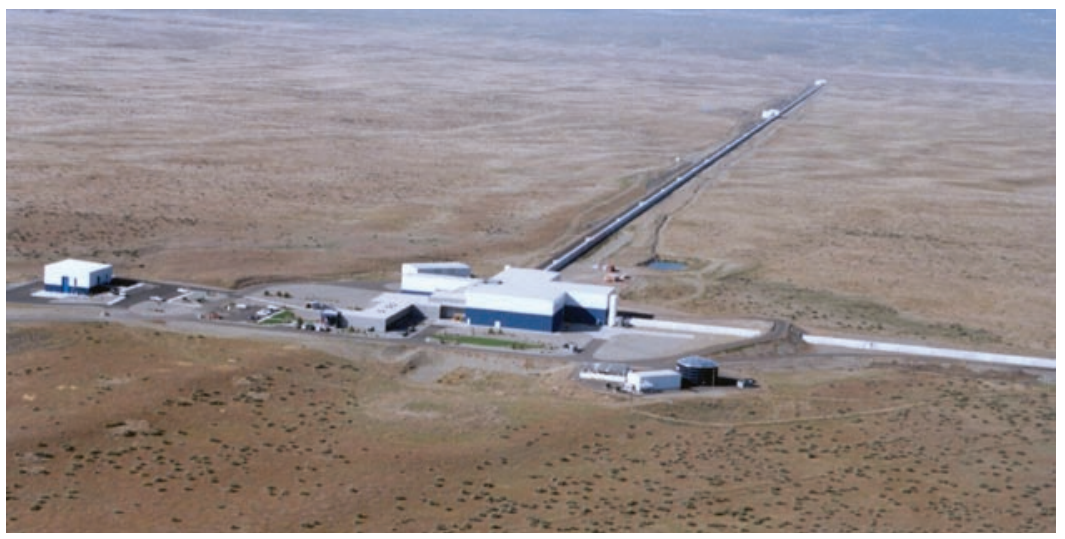

The Laser Interferometer GravitationalWave Observatory is located on Hanford Site leased land. is operated jointly by the California Institute of Technology and Massachusetts Institute of Technology with sponsorship by the National Science Foundation.

\section{SITE DESCRIPTION}

The Hanford Site lies within the semi-arid Pasco Basin of the Columbia Plateau in southeastern Washington State. The site, a relatively undeveloped area of shrub-steppe habitat (a drought-resistant, shrub and grassland ecosystem) containing a rich diversity of plant and animal species, occupies an area of approximately 586 square miles located north of the city of Richland. Public access to much of the site is restricted, and its large land area provides a buffer for the smaller areas on the site that historically were used for production of nuclear materials, waste storage, and waste disposal. The Columbia River flows eastward through the northern part of the Hanford Site and then turns south, forming part of the eastern site boundary.

In June 2000, the Hanford Reach National Monument was established on the site by Presidential Proclamation to protect the nation's only unimpounded stretch of the Columbia River above Bonneville Dam in

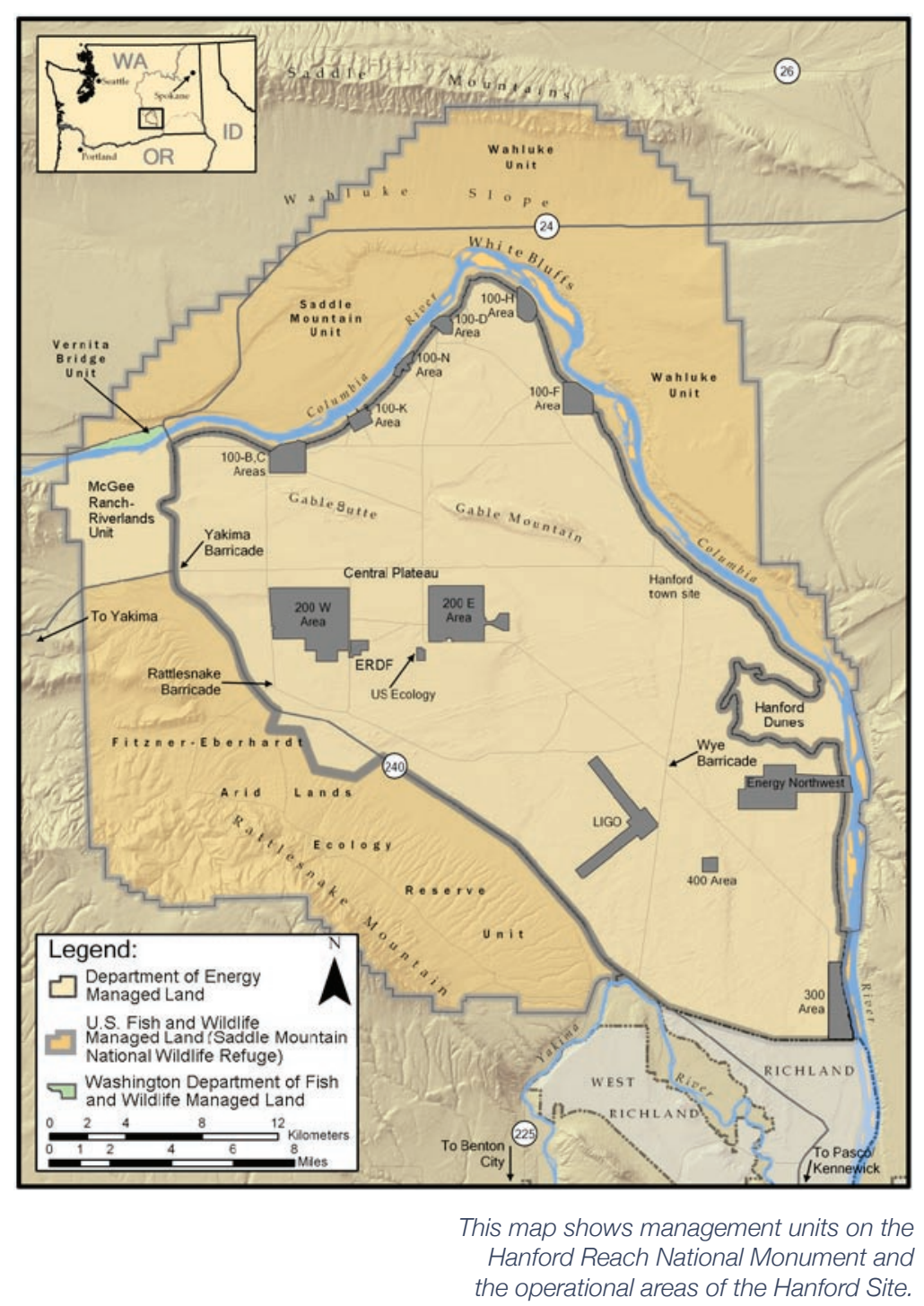




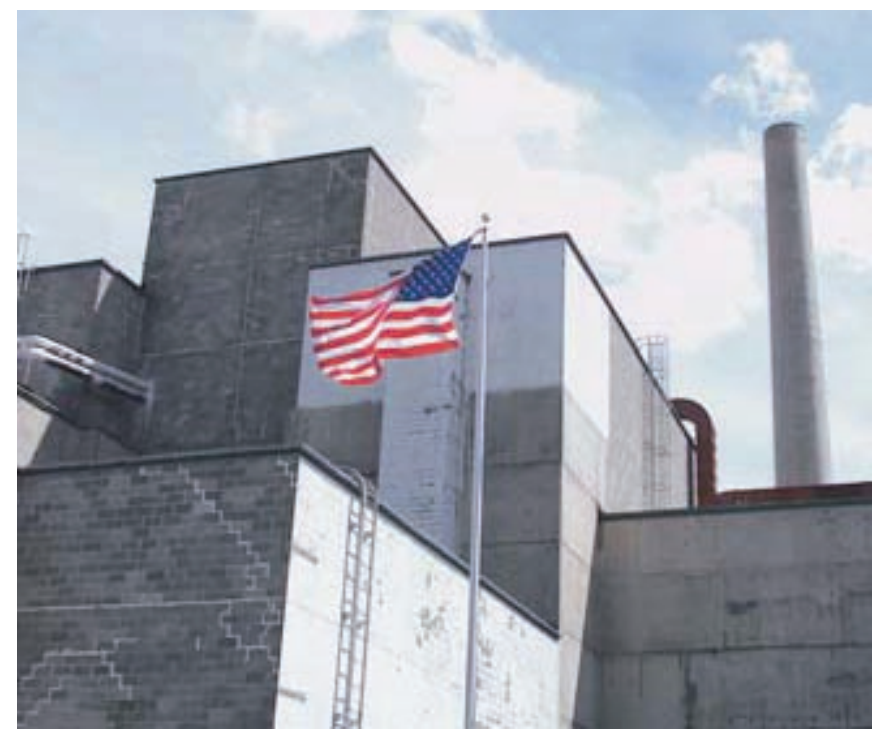

$B$ Reactor, located in the 100-B Area, was designated as a National Historic Landmark in 2008. the United States, as well as the remaining shrub-steppe ecosystem that once blanketed the Columbia River Basin. In 2008, the DOE, U.S. Fish and Wildlife Service, and Washington Department of Fish and Wildlife each managed units of the monument.

The DOE Richland Operations Office and DOE Office of River Protection jointly manage the Hanford Site through several contractors and their subcontractors. The DOE Richland Operations Office manages the cleanup of waste from historical operations, research, and other programs at the Hanford Site. The DOE Office of River Protection manages DOE's largest, most complex environmental cleanup project - retrieval, treatment, and disposal of tank waste at the Hanford Site.

The major DOE operational, research, and administrative areas on and around the Hanford Site include the following:

- 100 Areas - The 100 Areas, consisting of six distinct sites situated along the shore of the Columbia River in the northern portion of the site, were the location of nine nuclear reactors that have since been retired. The 100 Areas occupy approximately 4 square miles.

\section{HANFORD SITE AT A GLANCE}

\section{Location}

Dominant Features

Size

Employees

Mission

Site Management
The U.S. Department of Energy's Hanford Site is located in southeastern Washington State near the city of Richland.

Rattlesnake Mountain on the Fitzner/Eberhardt Arid Lands Ecology Reserve Unit of the Hanford Reach National Monument rises 3,525 feet above sea level, and the Columbia River flows through the northern and eastern part of the site.

The site covers approximately 586 square miles.

DOE and its contractors employed approximately 12,500 workers in 2008.

The Hanford Site mission is to safely clean up and manage the site's facilities and waste, and reduce the size of the site by releasing the land for other uses.

DOE's Richland Operations Office and Office of River Protection jointly manage the central portion of the Hanford Site through several contractors and their subcontractors. DOE, U.S. Fish and Wildlife Service, and Washington Department of Fish and Wildlife each manage units of the Hanford Reach National Monument. 
On August 19, 2008, the B Reactor, located in the 100-B Area, was designated as a National Historic Landmark. The B Reactor was the world's first industrial-scale nuclear reactor and where the plutonium was produced for the first atomic explosion (the Trinity Test) and the Nagasaki, Japan, atomic bomb. As a result of increased public interest, DOE has improved access to the reactor, offering additional tours of the site.

- 200 Areas - The 200-East and 200-West Areas are located on the Central Plateau, approximately 5 and 7 miles, respectively, south and west of the Columbia River. The plateau surface is approximately 328 feet above the level of the Columbia River and about 280 feet above the underlying water table. These areas contain underground waste storage tanks and housed facilities (known as "separations plants") that extracted plutonium from dissolved irradiated fuel. The 200-East and 200-West Areas cover approximately 6 square miles. The 200-North Area, now considered part of the 600 Area, is located near Gable Mountain, north of the 200-East and 200-West Areas and approximately 4 to 7.5 miles south of the 100 Areas. Covering approximately 0.1 square mile, the 200-North Area temporarily stored irradiated fuel.

- 300 Area - The 300 Area is located just north of the city of Richland and covers approximately 0.6 square mile. From the early 1940s until the advent of the cleanup mission, nuclear fuel fabrication and research and development activities at the Hanford Site were performed in the 300 Area.

- 400 Area - The 400 Area is located northwest of the 300 Area, and covers approximately 0.23 square mile. This area includes the Fast Flux Test Facility, which has not operated since 1992 and was undergoing deactivation during 2008. This nuclear reactor was designed and used to test various types of nuclear fuel, produce medical and industrial isotopes, and conduct cooperative international research.

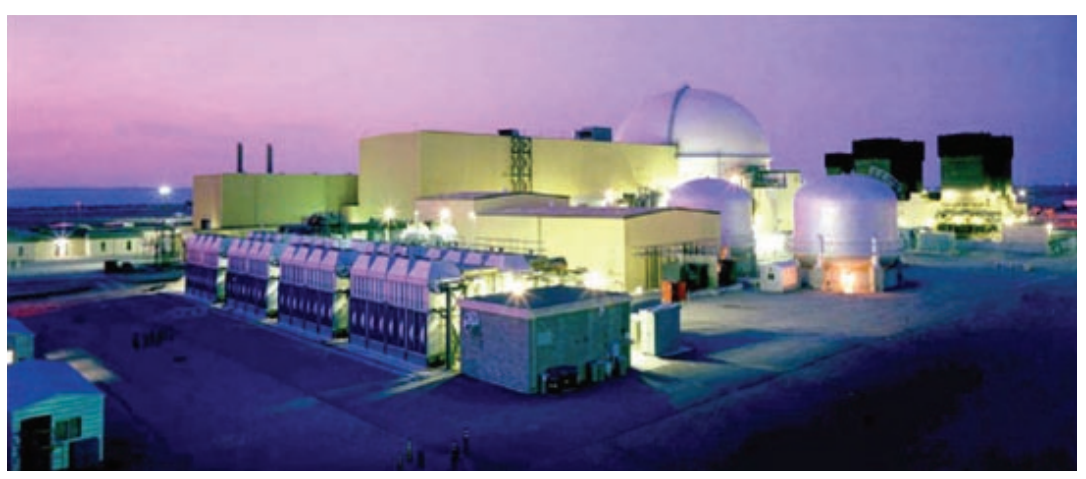

The Fast Flux Test Facility, once an active nuclear test reactor as pictured here, was undergoing deactivation during 2008.

- 600 Area - The 600 Area includes all of the Hanford Site not occupied by the 100, 200, 300, and 400 Areas.

- Former 1100 Area - The former 1100 Area, covering approximately 1.2 square miles, is located between the 300 Area and the city of 
Richland. In 1998, this area was transferred to the Port of Benton as part of the DOE Richland Operations Office economic diversification efforts and is no longer part of the Hanford Site. DOE contractors continue to lease facilities in this area.

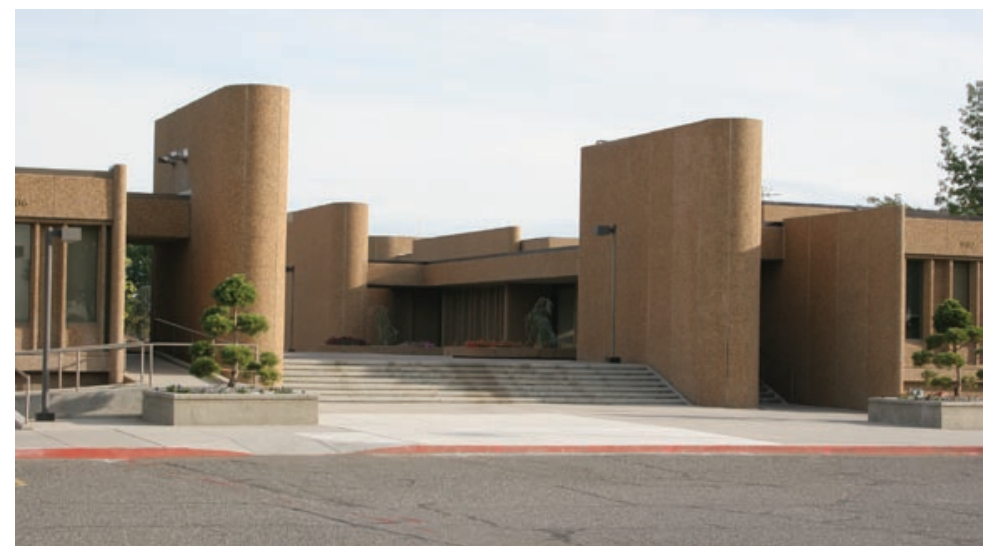

The Research Operations Building, part of the Pacific Northwest National Laboratory complex, is located south of the Hanford Site.

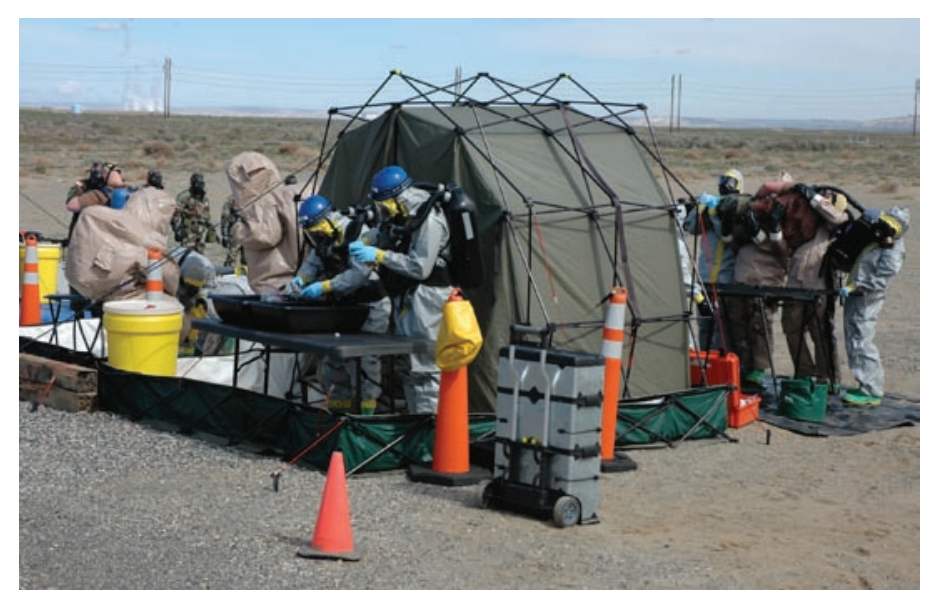

Worker safety and security training is conducted at the Volpentest Hazardous Materials Management and Emergency Response Training and Education Center on the Hanford Site.
- Richland North Area (off the site) - This area includes the Environmental Molecular Sciences Laboratory, Pacific Northwest National Laboratory, and other DOE and contractor facilities (mostly office buildings), generally located in the northern part of the city of Richland.

- 700 Area (off the site) - The 700 Area includes DOE administrative buildings in the central part of the city of Richland.

- Volpentest Hazardous Materials Management and Emergency Response Training and Education Center (also called HAMMER) This worker safety training facility is located on the site near the city of Richland. It consists of an 80-acre main site and a 10,000-acre law enforcement and security training site. The facility is owned by DOE, was managed by Fluor Hanford, Inc. during 2008, and is used by site contractors, federal and state agencies, tribal governments, and private industries.

\section{HANFORD SITE MISSION}

For more than 40 years, Hanford Site facilities were dedicated primarily to the production of plutonium for national defense and management of the resulting waste. In recent years, efforts at the site have focused on developing new waste treatment and disposal technologies, and the characterization and clean up of contamination left from historical operations. Physical challenges at the Hanford Site include managing or cleaning up millions of gallons of highly radioactive liquid waste in 177 underground storage tanks, 2,300 tons of spent nuclear fuel, 9 tons of plutonium in various forms, approximately 25 million cubic feet of buried or stored solid waste, more than 1,700 former waste disposal sites, and approximately 500 contaminated facilities. 
In 2008, DOE's primary mission was environmental remediation and cleanup, including the remediation of contaminated areas and the decontamination and decommissioning of Hanford Site facilities. The Performance Management Plan for the Accelerated Cleanup of the Hanford Site states the cleanup mission includes the following strategies:

- Restoring the Columbia River Corridor by accelerating cleanup of Hanford Site sources of radiological and chemical contamination that threaten the air, groundwater, or Columbia River. Most river corridor projects are expected to be complete by 2012 .

- Ending the tank waste program by 2033 by accelerating waste retrieval,

DOE's primary mission at the Hanford Site is to clean up facilities and contamination left from historical operations. increasing the capacity of the Hanford Tank Waste Treatment and Immobilization Plant (currently under construction), and continuing the process of closing underground waste storage tanks.

- Accelerating treatment and disposal of mixed low-level waste and the retrieval of transuranic waste and its shipment off the Hanford Site.

- Accelerating clean up of excess facilities on the Central Plateau (200-East and 200-West Areas).

- Accelerating clean up and protection of groundwater beneath the Hanford Site.

- Cleaning up other Hanford Site facilities that are considered urgent risks.

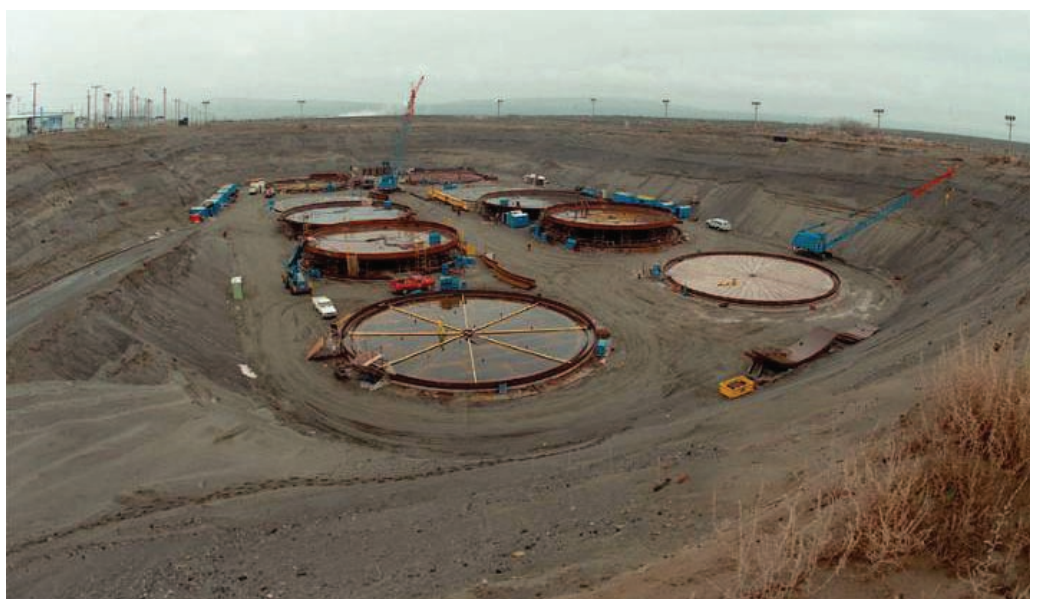

The construction of double-shell tanks between 1968 and 1985 allowed the transfer of wastes from leaking single-shell tanks. The current Hanford Site mission includes managing and treating this waste. 


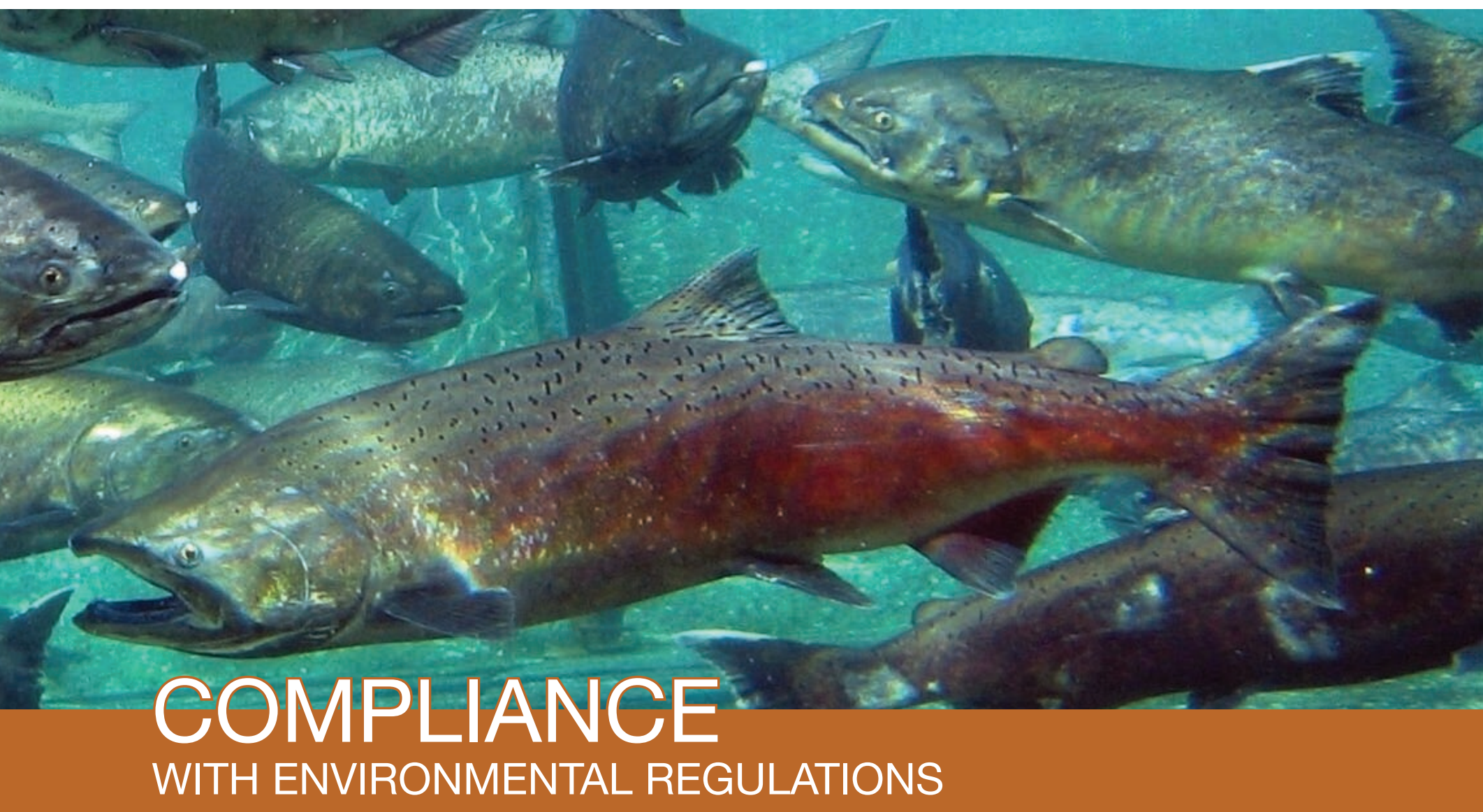

Chinook salmon are found in the Columbia River and spawn in the Hanford Reach. The spring-run of Chinook salmon are listed under the Endangered Species Act of 1973 as an endangered species. Photo courtesy of Geoffrey McMichael.
Federal, state, and local government agencies monitor and enforce compliance with applicable environmental regulations at the Hanford Site. Major agencies include the U.S. Environmental Protection Agency (EPA), Washington State Department of Ecology, Washington State Department of Health, and Benton Clean Air Agency. These agencies issue permits, review compliance reports, participate in joint monitoring programs, inspect facilities and operations, and/or oversee compliance with regulations. A key feature in the Hanford Site compliance program is the Hanford Federal Facility Agreement and Consent Order (also known as the Tri-Party Agreement). The Tri-Party Agreement is an agreement between DOE, EPA, and the Washington State Department of Ecology delineating specific requirements, actions, plans, and schedules required to achieve compliance with the Comprehensive Environmental Resource, Compensation, and Liability Act of 1980 (CERCLA) and Resource Conservation and Recovery Act of 1976 (RCRA) regulations and provisions. The Tri-Party Agreement is continually evolving and is under review to meet changing conditions as cleanup requirements have progressed.

Both the DOE Richland Operations Office and DOE Office of River Protection recognize the importance of maintaining a program of self-assessment 
and regulatory reporting to assure that environmental compliance is achieved and maintained at the Hanford Site.

Compliance with federal acts in 2008 is summarized in the following table.

\section{COMPLIANCE WITH FEDERAL ACTS ON THE HANFORD SITE IN 2008}

\section{Regulation}

American Indian Religious Freedom Act; Antiquities Act of 1906; Archaeological and Historic Preservation Act of 1974; Archaeological Resources Protection Act of 1979; Historic Sites, Buildings, and Antiquities Act; National Historic Preservation Act of 1966; and Native American Graves Protection and Repatriation Act of 1990

Atomic Energy Act of 1954 Proper management of radioactive materials.

\begin{tabular}{ll}
\hline Clean Air Act & Air quality, including emissions \\
& from facilities and from \\
unmonitored sources.
\end{tabular}

Clean Water Act of 1977

Point-source discharges to U.S. surface waters.

Cultural resources.

\section{Status}

During 2008, 113 cultural resource reviews were requested on the Hanford Site. DOE determined that 103 activities would not affect cultural resources and were exempt from further review; 10 requests required full reviews. Forty-five cultural resources sites were visited in 2008 to assess the effects of erosion, weathering, and unauthorized excavation and collection. Fifteen new archaeological sites and 15 new isolated finds were recorded on the Hanford Site in 2008.

In 2008, six DOE regulations and directives pertaining to the management and control of radioactive materials on the Hanford Site were issued or underwent significant revision. In addition, six technical standards or handbooks underwent significant revisions.

In coordination with the Washington State Department of Health and the Benton Clean Air Authority, the Washington State Department of Ecology issued Renewal 1 of the Hanford Site air operating permit for a period of 5 years, effective January 1 , 2007. One revision to the air operating permit was approved in 2008. The Washington State Department of Health, the Washington State Department of Ecology, and the Benton Clean Air Agency conducted over 25 inspections in 2008.

The Hanford Site has one National Pollutant Discharge Elimination System permit, one storm water permit, and several state sanitary wastewater discharge permits. There were no permit violations in 2008. hazardous materials.
Comprehensive Environmental Sites already contaminated by Response, Compensation, and Liability Act of 1980 (CERCLA)

Institutional controls are implemented and maintained in accordance with CERCLA decision documents. During 2008, field inspections of institutional controls at waste sites were performed in the 100-IU-2 and 100-IU-6 Operable Units, three burial grounds in the 300-FF-2 Operable Unit, and at the Environmental Restoration Disposal Facility. Warning sign information was updated at two of the inactive burial grounds in the 300 Area in response to this inspection. Trespass events and excavation permit use were reviewed in 2008; no findings were identified.

\begin{tabular}{ll}
\hline Emergency Planning \& Community & The public's right to informa- \\
Right-to-Know Act of 1986 & tion about hazardous materials \\
& in the community and the \\
& establishment of emergency \\
planning procedures.
\end{tabular}

In early 2009, Hanford Site officials issued the 2008 Hanford Site Tier Two Emergency and Hazardous Chemical Inventory report to the Washington State Department of Ecology's Community RightTo-Know Unit; local emergency planning committees for Benton, Franklin, and Grant Counties; and both the city of Richland and Hanford Site fire departments. The 2008 Hanford Site Toxic Chemical Release Inventory was released in June 2009.

Endangered Species Act of $1973 \quad$ Rare plant and animal species.

Numerous plants and animals on the Hanford Site are federal- or state-listed as endangered, threatened, sensitive, or candidate species. Ecological compliance reviews are conducted prior to project initiation on the Hanford Site to prevent adverse impacts to biological resources, including listed species. In 2008, 202 reviews were performed, including 91 ecological compliance reviews for general site activities and 111 reviews for environmental restoration activities.

Federal Insecticide, Fungicide, and Storage and use of pesticides. Rodenticide Act of 1975
On the Hanford Site, pesticides are applied by commercial pesticide operators licensed by the state. 


\section{COMPLIANCE WITH FEDERAL ACTS ON THE HANFORD SITE IN 2008}

\section{Regulation}

Migratory Bird Treaty Act$$
\text { National Environmental Policy Act of }
$$
1969 (NEPA)

Resource Conservation and Recovery Act of 1976 (RCRA)

Safe Drinking Water Act of 1974

Drinking water systems.
Pollution Prevention Act of 1990

\section{What It Covers}

Migratory birds or their feathers, nests, or eggs.

Environmental impact statements for major federal projects that have the potential to significantly affect the quality of the human environment.
Reduction or prevention of wastes by treatment, control, reuse, and/or recycling.

Tracking hazardous waste from generator to treatment, storage, or disposal (referred to as cradle-to-grave management).

\section{Status}

All Hanford Site projects with a potential to affect federal- or statelisted species of concern complied with the requirements of this act by using an ecological compliance review process to minimize adverse impacts to migratory birds.

In October 2008, DOE released the Draft Global Nuclear Energy Partnership Programmatic Environmental Impact Statement, providing an analysis of the potential environmental consequences of alternatives to the present open fuel cycle, in which nuclear fuel is used one time and sent to geologic disposal. A supplemental analysis to the 1999 Hanford Comprehensive Land-Use Plan Environmental Impact Statement was issued in August 2008. The Draft Planning Report/Environmental Impact Statement Yakima River Basin Water Storage Feasibility Study, Yakima Project, Washington, was released in January 2008; the final version was published in December 2008 for public comment. The Final Conservation Plan and Environmental Impact Statement for the Hanford Reach National Monument was issued in August 2008; the Record of Decision was issued in November 2008. Two draft environmental impact statements were in preparation in 2008: 1) the environmental impact statement for the disposal of greater-than-Class-C lowlevel radioactive waste; and 2) the Tank Closure and Waste Management Environmental Impact Statement.

In 2008, 1,690 tons of sanitary and hazardous wastes were recycled through site-wide programs on the Hanford Site.

DOE is operating under an expired facility RCRA permit at the Hanford Site while the Washington State Department of Ecology drafts a new permit. During 2008, 40 revisions to the Hanford Facility RCRA Permit Part A Form and 1 RCRA Part B Permit application were submitted to the state for review and approval. One treatment, storage, and disposal unit was approved for closure in 2008. Washington State Department of Ecology performed 28 RCRA inspections on the Hanford Site during 2008 to assess compliance with applicable requirements. Two RCRA noncompliance documents were received at the Hanford Site in 2008: 1) violations involving dangerous waste designation at the T Plant Complex; and 2) violations for the removal and shipment of anhydrous ammonia cylinders from the 100-N Area. All issues were resolved with no impact to the environment.

There were nine public drinking water systems on the Hanford Site in 2008. The systems were monitored for radiological and chemical contaminants and disinfection residuals and byproducts. There were no microbiological detections during 2008, and all chemical concentrations in Hanford Site drinking water were well below the maximum contaminant levels established by the EPA. Systems demonstrated compliance with the filtration and disinfection treatment technique requirements and limits for disinfectant residuals and disinfection byproducts.

Toxic Substances Control Act

Hazardous chemical regulation and tracking; primarily polychlorinated biphenyls (PCBs).
During 2008, the 2007 PCB annual document log report for the Hanford Site and a 2007 PCB annual report were submitted to the EPA as required. EPA-approved risk-based disposal approvals were used in 2008 for retrieving waste from selected single-shell underground waste storage tanks; for the removal of containers of treated sludge from the K-East Basin; and continued storage of two water tower tanks containing PCB-contaminated paint. 


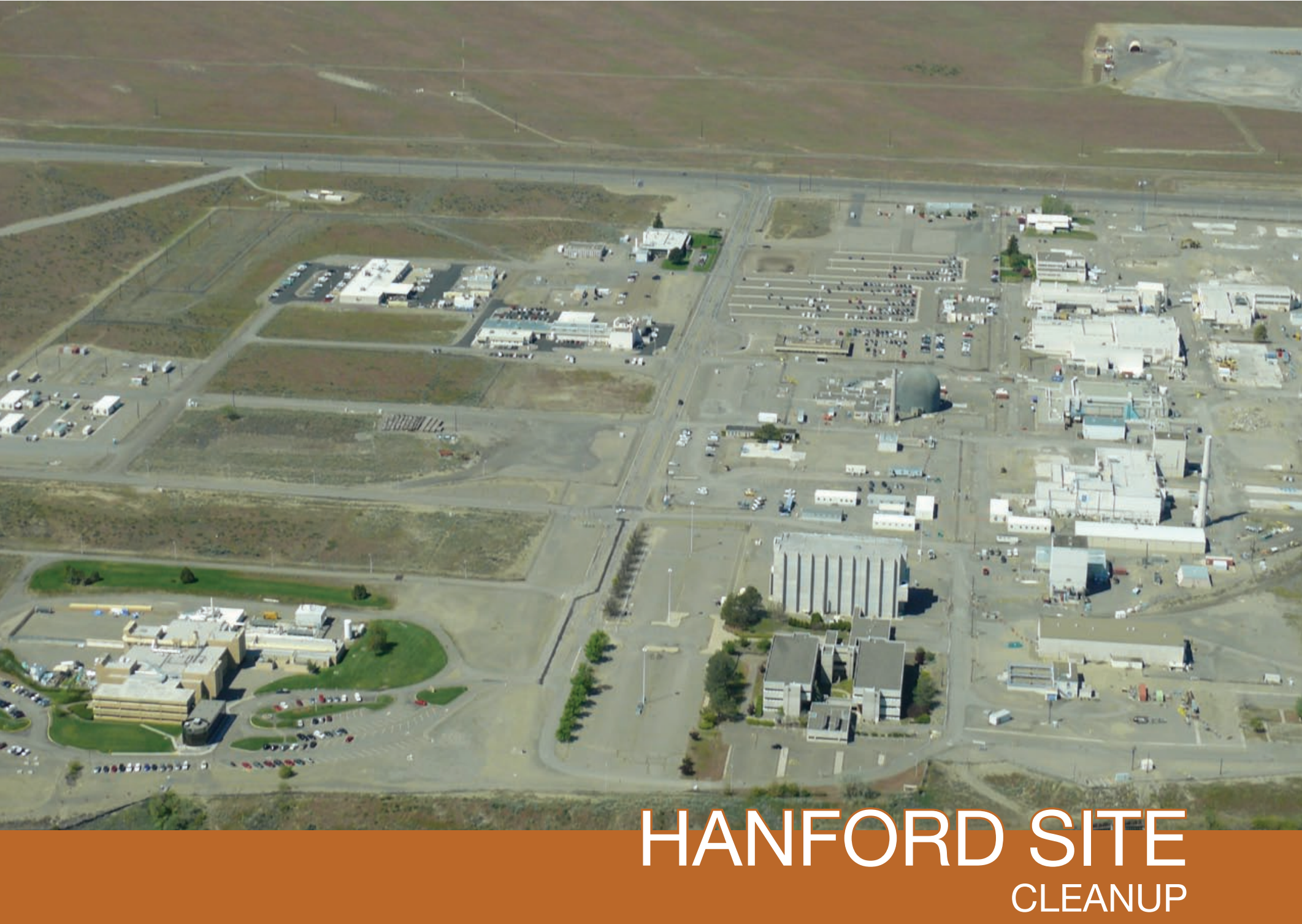

Cleanup of the 300 Area continued during 2008 with the removal of 180,000 tons of contaminated soil. Photo courtesy of Robert Mueller.

\section{CLEANUP OPERATIONS IN 2008}

Hanford Site cleanup includes remediation of former waste disposal sites and decommissioning of inactive facilities.

Since cleanup activities began at the Hanford Site, the primary focus has been on former liquid effluent waste disposal sites. After nearly 10 years of work, the number of liquid effluent waste disposal sites requiring remediation has been reduced, and cleanup activities are now turning to remediation of waste burial grounds. The volume of contamination in waste burial grounds is less than in liquid effluent waste disposal sites; however, the burial grounds may 


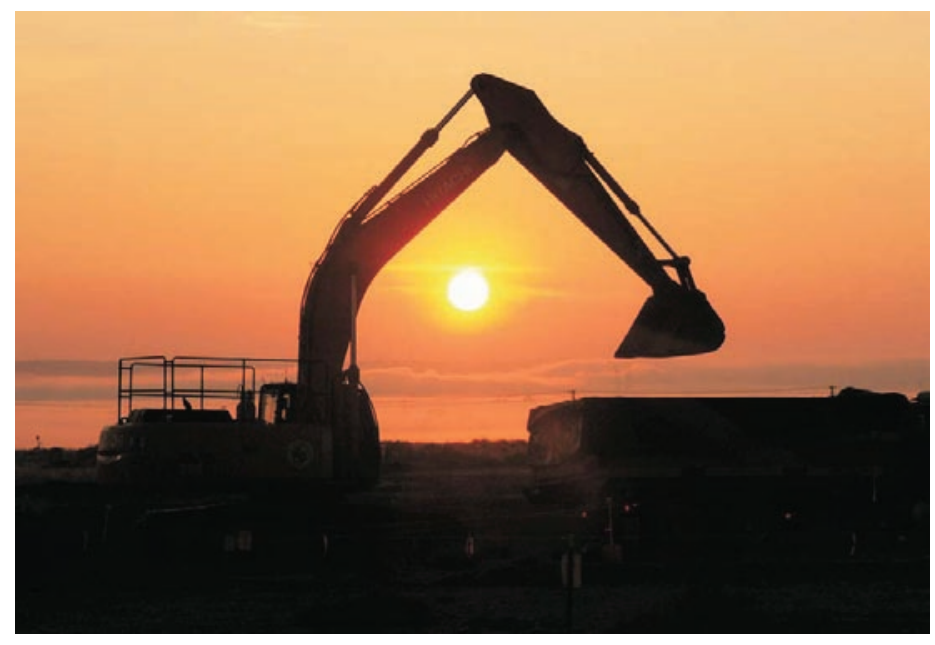

Over 400,000 tons of contaminated soil was removed from waste sites in the 100 Areas to the Environmental Restoration and Disposal Facility. contain unknown materials and additional time may be required to characterize the materials and dispose of them properly.

Remediation of Waste Sites in the 100 Areas. Full-scale remediation of waste sites began in the 100 Areas in 1996. In 2008, remediation focused on waste burial grounds and miscellaneous waste sites in the $100-\mathrm{B} / \mathrm{C}, 100-\mathrm{K}, 100-\mathrm{D}, 100-\mathrm{H}$, and $100-F$ Areas. A total of 405,125 tons of contaminated soil from 100 Areas remediation activities were disposed of at the Environmental Restoration Disposal Facility (near the 200-West Area) during 2008. The bulk of the contaminated soil was from the 100-D and 100-F Areas. Remediated waste sites in the 100-F Area were revegetated with native grass seed and bitterbrush, hopsage, and sagebrush seedlings in 2008.

K Basins Closure Activities. During 2008, workers continued to clean out the K Basins, which are two indoor, concrete pools attached to the now-closed

\section{SUMMARY OF GROUNDWATER REMEDIATION ACTIVITIES}

\begin{tabular}{|c|c|c|c|c|}
\hline Location & $\begin{array}{l}\text { Startup } \\
\text { Date }\end{array}$ & Contaminant & $\begin{array}{c}\text { Mass Removed } \\
\underline{2008}\end{array}$ & $\begin{array}{l}\text { Mass Removed } \\
\text { Since Startup }\end{array}$ \\
\hline $\begin{array}{l}\text { 100-D Area (100-DR-5 Pump- } \\
\text { and-Treat System) }\end{array}$ & 2004 & Chromium & 112 pounds & 465 pounds \\
\hline $\begin{array}{l}\text { 100-D Area (100-HR-3-D } \\
\text { Pump-and-Treat System) }\end{array}$ & 1997 & Chromium & 50 pounds & 630 pounds \\
\hline $\begin{array}{l}\text { 100-H Area (100-HR-3-H } \\
\text { Pump-and-Treat System) }\end{array}$ & 1997 & Chromium & 4 pounds & 112 pounds \\
\hline $\begin{array}{l}\text { 100-K Area (100-KR-4 Pump- } \\
\text { and-Treat System) }\end{array}$ & 1997 & Chromium & 40 pounds & 728 pounds \\
\hline $\begin{array}{l}\text { 100-K Area (Pump-and-Treat } \\
\text { System near K-West Reactor) }\end{array}$ & 2007 & Chromium & 33.2 pounds & 68 pounds \\
\hline $\begin{array}{l}\text { 200-West Area (200-ZP-1 } \\
\text { Pump-and-Treat System) }\end{array}$ & 1994 & Carbon tetrachloride & 1,000 pounds & 25,000 pounds \\
\hline \multirow{4}{*}{$\begin{array}{l}\text { 200-West Area (200-UP-1 } \\
\text { Pump-and-Treat System) }\end{array}$} & 1994 & Carbon tetrachloride & 6.6 pounds & 83 pounds \\
\hline & & Nitrate & 14,100 pounds & 91,500 pounds \\
\hline & & Technetium-99 & 0.01 pound & 0.27 pound \\
\hline & & Uranium & 7.7 pounds & 476 pounds \\
\hline $\begin{array}{l}\text { Waste Management } \\
\text { Area S-SX }\end{array}$ & 2003 & Technetium-99 & 0.003 ounce & 0.01 ounce \\
\hline $\begin{array}{l}\text { 200-West Area (Soil-Vapor } \\
\text { Extraction System) }\end{array}$ & 1991 & Carbon tetrachloride & 440 pounds & 175,000 pounds \\
\hline
\end{tabular}


K-East and K-West Reactors. For nearly 30 years, these basins contained 2,300 tons of Hanford Site N Reactor spent fuel and a small quantity of irradiated single-pass reactor fuel from older site reactors. This fuel was removed in a major effort that ended in 2004 but fuel corrosion left behind sludge and debris. During 2008, K Basins cleanup continued with the removal of debris from both the K-East and K-West Basins. All sludge from the K-East Basin was removed, completing deactivation and allowing the start of decommissioning activities, including the demolition of the K-East Basin structural steel superstructure.

\section{Remediation of Waste Sites on the Central Plateau.}

Remedial investigation and feasibility study activities con-

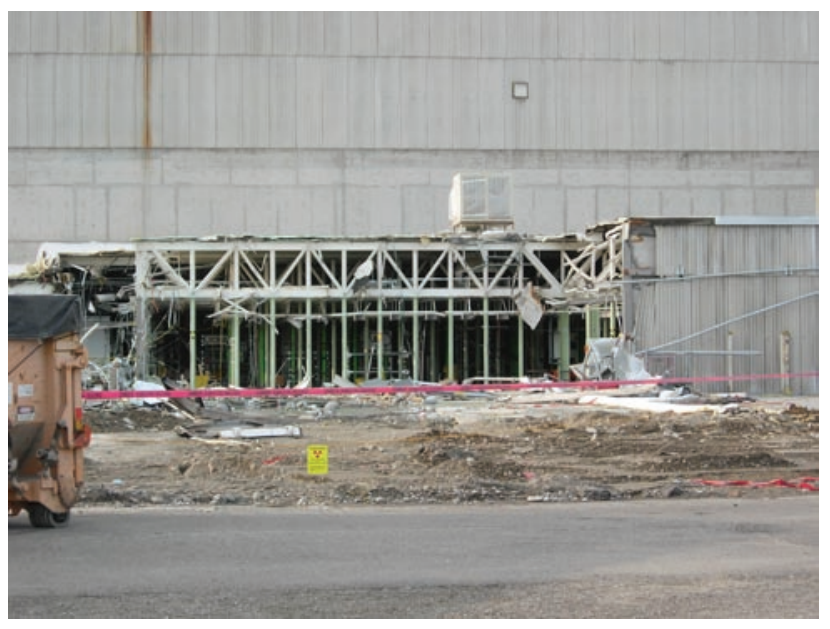

K-East Basin structural steel tinued during 2008 in the 200-East and 200-West Areas at waste sites that are grouped into a number of CERCLA operable unit groups.

Remediation of Waste Sites in the 300 Area. In 2008, 180,000 tons of contaminated soil from 300 Area waste sites were removed and disposed of at the Hanford Site's Environmental Restoration Disposal Facility. The 618-7 Burial Ground, located just west of the 300 Area, was remediated in 2008.

\section{FACILITY}

\section{DECOMMISSIONING AND \\ DEACTIVATION ACTIVITIES IN 2008}

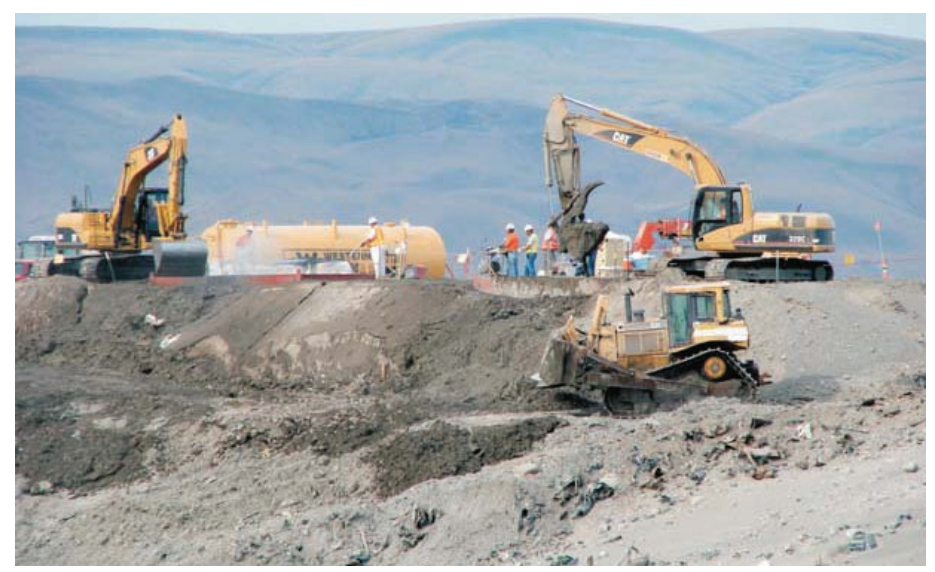

Decommissioning of Facilities in the 100 Areas. Decontamination and decommissioning activities focused on the 100-N Area in 2008, where 30 structures (buildings and facility stacks) were demolished.

Decommissioning of Facilities on the Central Plateau. Surveillance, maintenance, and decontamination or stabilization of over 500 waste sites, including former waste disposal cribs, ponds, ditches, trenches, unplanned release sites, and waste burial grounds in the 200-East, 200-West, and 200-North Areas, and a few waste sites on the Fitzner/ Eberhardt Arid Lands Ecology Reserve Unit, continued in 2008. Periodic surveillances, radiation surveys, and pesticide and herbicide applications were conducted. Activities at the Plutonium Finishing Plant included the stabilization and packaging of plutonium for

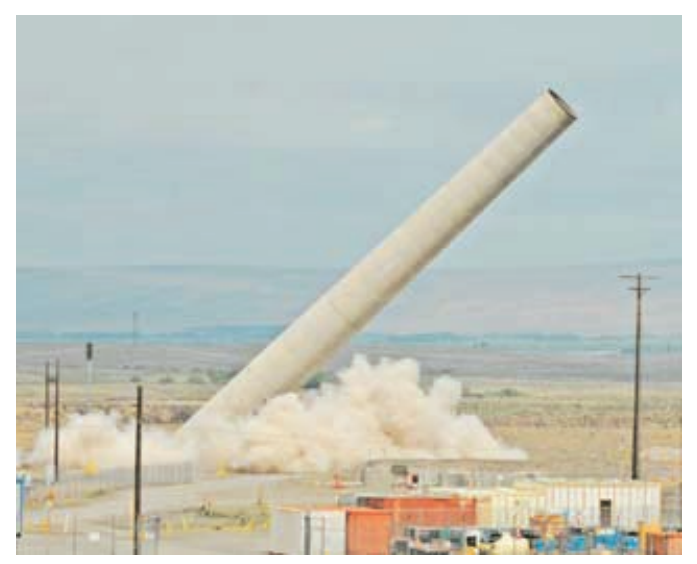

The 116-N Air Stack was demolished as part of Hanford Site decommissioning activities in 2008. 


\section{What is decommissioning?}

When DOE declares a facility as surplus (no longer needed), it is shut down and prepared for decontamination and decommissioning (D\&D). The process is the safe decontamination, dismantling, removal of contamination and structures, and/or the release for reuse of facilities that are no longer active. DOE is conducting $D \& D$ activities on reactors, processing plants, storage tanks, laboratory facilities, and other structures. Decontamination and decommissioning presents many challenges. Work continues at the Hanford Site to decommission facilities in the operational areas.

\section{Adapted from}

http://www.lanl.gov/environment/cleanup/ dd.aspx

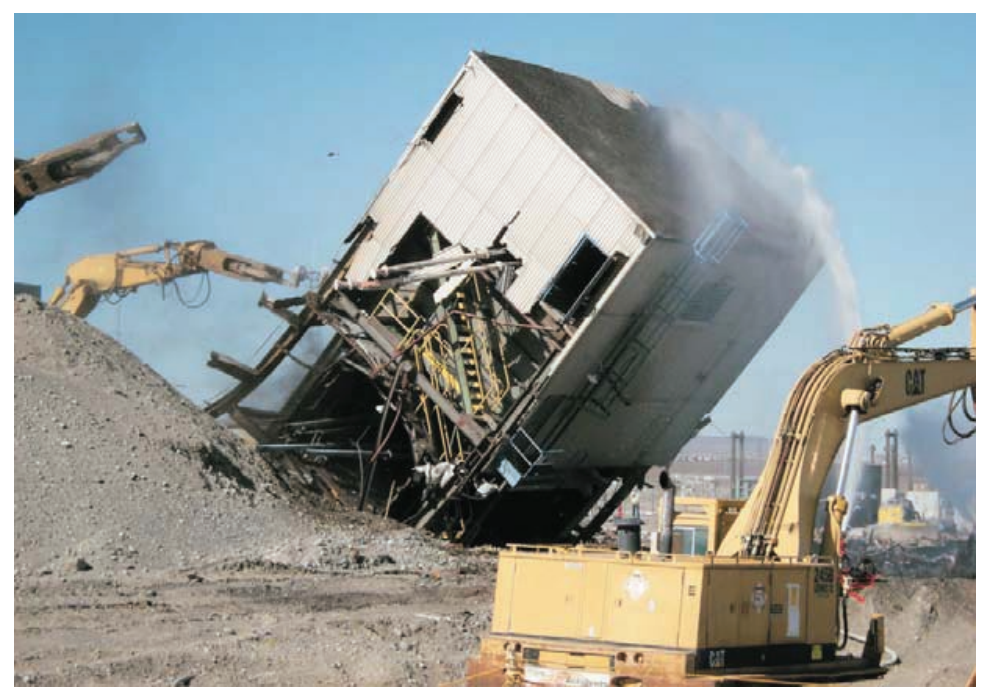

The 384 High Bay was 1 of 15 facilities and buildings demolished in the 300 Area in 2008. shipment to the Savannah River Site in South Carolina; continued cleanout of contaminated equipment; leak testing of plutonium shipping containers; and draining and blanking the hydrofluoric acid lines in the main Plutonium Finishing Plant process building.

Decommissioning of Facilities in the 300 Area. Deactivation, decontamination, decommissioning, and demolition activities continued in the 300 Area during 2008, focusing on facility and building removal. Fifteen facilities and buildings were demolished in the 300 Area in 2008.

Deactivation of Facilities in the 400 Area - Fast Flux Test Facility. After multiple studies, a final decision was made by DOE to complete facility deactivation, including removing all nuclear fuel, draining the liquid-sodium systems, and deactivating systems and equipment to place the facility in a low-cost, long-term surveillance and maintenance condition by September 2009. During 2008, fuel removal from the 400 Area Property Protected Area was completed. Deactivation activities continued in 2008, including shipment of four polychlorinated biphenyl-laden transformers for disposal, the shutdown of operating systems (electric, fire suppression, water, ventilation, etc.), and cleanout and closure of the reactor containment building and supporting facilities. 


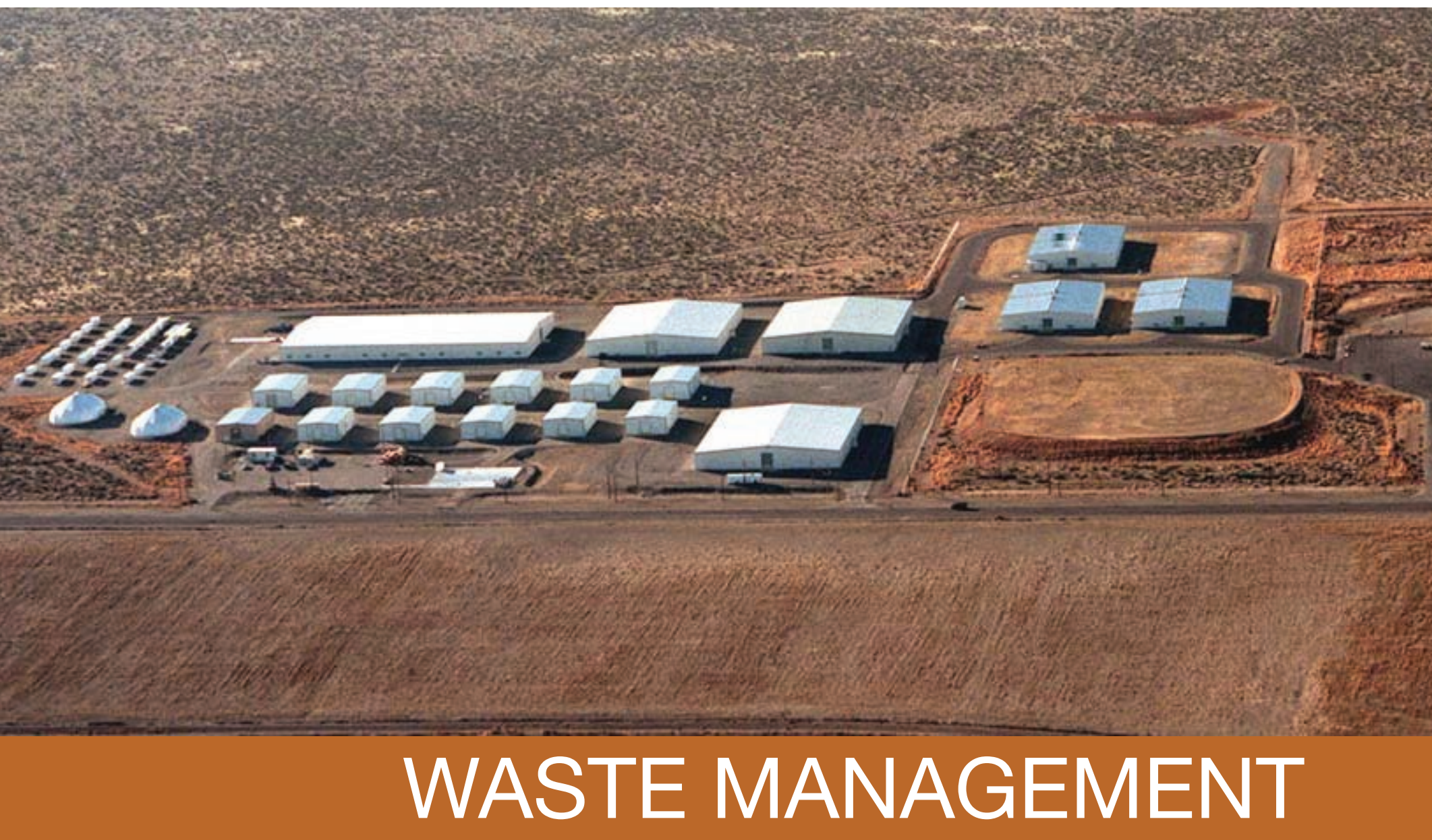

The Central Waste Complex stored 9,800 cubic yards of waste in 2008.

Hanford Site cleanup activities generate non-regulated, non-radioactive, radioactive, mixed, and hazardous waste. Mixed waste contains both radioactive and hazardous non-radioactive substances. Hazardous waste contains either dangerous waste or extremely hazardous waste, or both. This waste is handled and prepared for safe storage at the site or shipped to offsite facilities for treatment and disposal.

In addition to newly generated waste, significant quantities of waste remain from years of nuclear materials production and waste management activities. Most waste from past operations at the Hanford Site resides in underground storage tanks and in former waste disposal sites, or is temporarily stored until it can be cleaned up, disposed, or placed in permanent safe storage.

Management of Solid Waste. Waste management at the Hanford Site in 2008 included the treatment, storage, and disposal of solid waste. Onsite solid waste facilities include the Central Waste Complex, Waste Receiving 
and Processing Facility, T Plant Complex, Environmental Restoration Disposal Facility, Radioactive Mixed Waste Disposal Facility, and low-level burial grounds.

The Central Waste Complex can store as much as 27,200 cubic yards of waste. This capacity is adequate to store the projected volumes of low-level, transuranic, and mixed waste, and radioactively contaminated polychlorinated biphenyls to be generated from

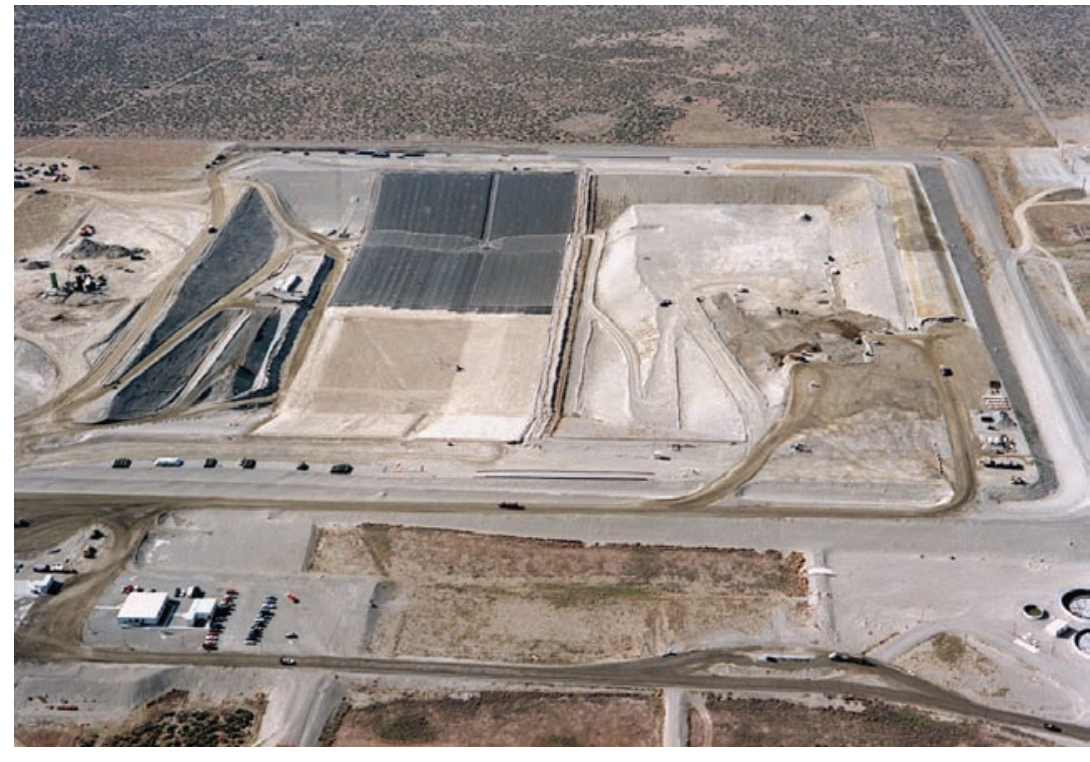

The Environmental Restoration Disposal Facility, located adjacent to the 200-West Area, was constructed to RCRA minimum technology requirements, including a double liner and leachate collection system. Hanford Site cleanup activities assuming on-schedule treatment of the stored waste. Treatment will reduce the amount of waste in storage and make room for newly generated mixed waste. In 2008, the volume of waste stored at this complex totaled approximately 9,800 cubic yards.

Waste destined for the Waste Receiving and Processing Facility includes stored waste as well as newly generated waste from current site cleanup activities. The waste consists primarily of contaminated cloth, paper, rubber, metal, and plastic. This facility treated and shipped 673 cubic yards of waste offsite in 2008 .

The T Plant Complex in the 200-West Area provides waste treatment, storage, and decontamination services for the Hanford Site and for offsite facilities. In 2008, one thousand, five hundred and twenty-eight 55-gallon drum equivalents of transuranic waste were repackaged to meet offsite waste acceptance criteria.

During 2008, there were 1,070 cubic yards of mixed low-level waste treated or disposed of at the Mixed Low-Level Waste Treatment and Disposal Facility.

There was one defueled reactor compartment from the U.S. Navy shipped to Trench 94 in the 200-East Area in 2008. The total number of Navy reactor compartments received to date is 118 .

During 2008, approximately 708,600 tons of remediation wastes were disposed of at the Environmental Restoration Disposal Facility. Approximately 7.9 million tons of remediation waste have been disposed of at the Environmental Restoration Disposal Facility from initial operations startup through 2008. 


\section{HANFORD SITE WASTE SUMMARY FOR 2008}

\begin{tabular}{|c|c|c|}
\hline Activity & Waste Type & Amount \\
\hline \multirow[t]{2}{*}{ Solid waste generated during onsite cleanup activities } & Solid mixed waste & 346 tons \\
\hline & Radioactive waste & 398 tons \\
\hline \multirow{2}{*}{$\begin{array}{l}\text { Solid waste received at the Hanford Site from offsite (includes Hanford Site } \\
\text { generated waste treated by an offsite contractor and returned to the Hanford Site as } \\
\text { newly generated waste) }\end{array}$} & Solid mixed waste & 459 tons \\
\hline & Radioactive waste & 445 tons \\
\hline \multirow[t]{3}{*}{ Dangerous waste shipped off the Hanford Site } & $\begin{array}{l}\text { Containerized waste } \\
\text { (dangerous waste only) }\end{array}$ & 128 tons \\
\hline & Bulk solids & 0 \\
\hline & Bulk liquids & 221 tons \\
\hline $\begin{array}{l}\text { Waste volume pumped from underground single-shell waste storage tanks to double- } \\
\text { shell waste storage tanks }\end{array}$ & $\begin{array}{l}\text { Liquid waste } \\
\text { (includes flush/dilution water) }\end{array}$ & 69 thousand gallons \\
\hline Waste volume in underground single-shell waste storage tanks at the end of 2008 & Liquid waste & 29.8 million gallons \\
\hline Waste volume evaporated at the 242-A Evaporator & Liquid waste & 0 \\
\hline Waste added to underground double-shell waste storage tanks & Liquid waste & 85 thousand gallons \\
\hline Waste volume in underground double-shell waste storage tanks at the end of 2008 & Liquid waste & 26.7 million gallons \\
\hline $\begin{array}{l}\text { Waste dispositioned and shipped offsite from the Waste Receiving and Processing } \\
\text { Facility }\end{array}$ & Solid waste & 674 cubic yards \\
\hline $\begin{array}{l}\text { Waste treated or directly disposed of at the Mixed Low-Level Waste Treatment and } \\
\text { Disposal Facility }\end{array}$ & Mixed low-level solid waste & 1,070 cubic yards \\
\hline Waste disposed of at the Environmental Restoration Disposal Facility & Solid waste & 708,600 tons \\
\hline Volume of aqueous waste received at the Liquid Effluent Retention Facility & $\begin{array}{l}\text { Wastewater containing low levels of } \\
\text { organic compounds and tritium }\end{array}$ & 17.2 million gallons \\
\hline Volume of liquid effluent treated at the Effluent Treatment Facility & $\begin{array}{l}\text { Wastewater containing toxic metals, } \\
\text { radionuclides, ammonia, and } \\
\text { organic compounds }\end{array}$ & 18 million gallons \\
\hline Volume of wastewater treated at the 242-A Evaporator & Liquid waste from single-shell tanks & 0 \\
\hline Volume of effluent disposed of at the 200 Area Treated Effluent Disposal Facility & $\begin{array}{l}\text { Uncontaminated, treated liquid } \\
\text { waste }\end{array}$ & 73 million gallons \\
\hline $\begin{array}{l}\text { Volume of wastewater treated and disposed of at the } 300 \text { Area Treated Effluent } \\
\text { Disposal Facility }\end{array}$ & Industrial wastewater & 42.4 million gallons \\
\hline
\end{tabular}

The Radioactive Mixed Waste Disposal Facility consists of two trenches (Trench 31 and Trench 34) in the 200-West Area. Disposal to Trench 34 began in 1999 and the first waste layer was completed and covered with compacted gravel and soil. The second waste layer has been started and is approximately half filled. In 2008, there were approximately 5,400 cubic yards of waste in Trench 34 and approximately 3,490 cubic yards of waste in Trench 31, which began receiving waste in 2005 .

The low-level burial grounds consist of eight burial grounds located in the 200-East and 200-West Areas that are used for disposal of low-level waste and mixed waste (i.e., low-level radioactive waste with a dangerous waste component).
Nearly 30 million gallons of waste remained in single-shell underground waste storage tanks at the end of 2008. 


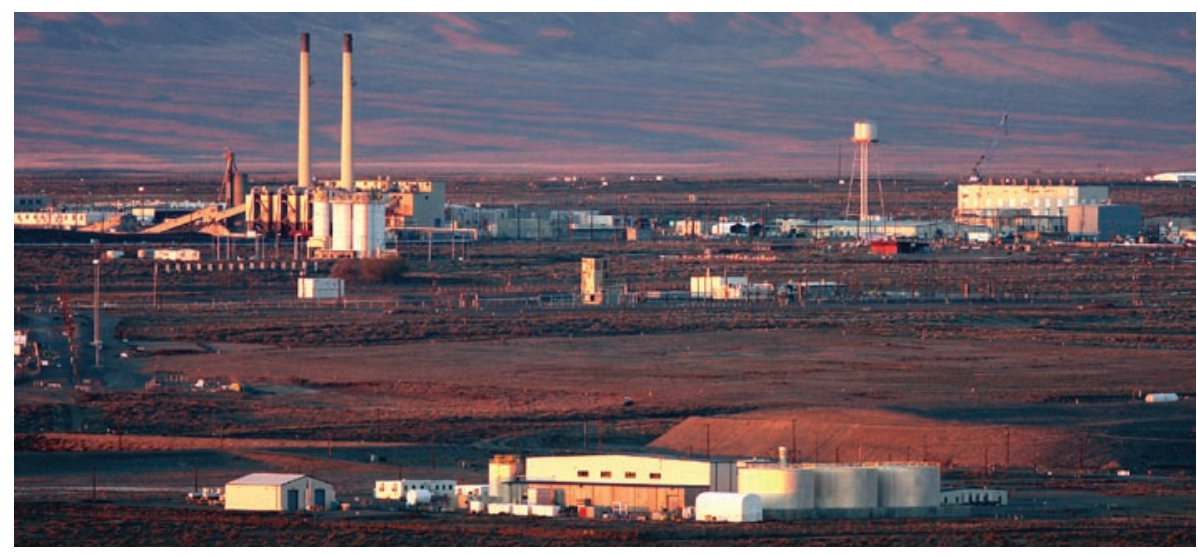

The Integrated Disposal Facility, completed in 2006 and currently not operational, is an expandable RCRA-compliant landfill located in the south-central part of the 200-East Area. The facility will receive immobilized low-activity tank waste and other low-level radioactive waste from the Hanford Tank Waste Treatment and Immobilization Plant.

The Effluent Treatment Facility treated and disposed of approximately 18 million gallons of waste in 2008. Photo courtesy of Mike Guthrie.

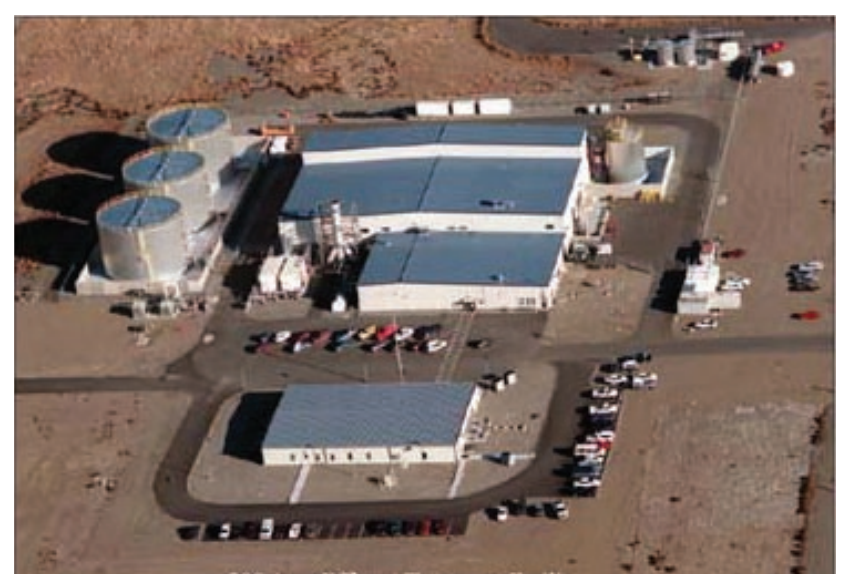

In 2008, approximately 73 million gallons of uncontaminated effluent were disposed of at the 200 Area Treated Effluent Disposal Facility.

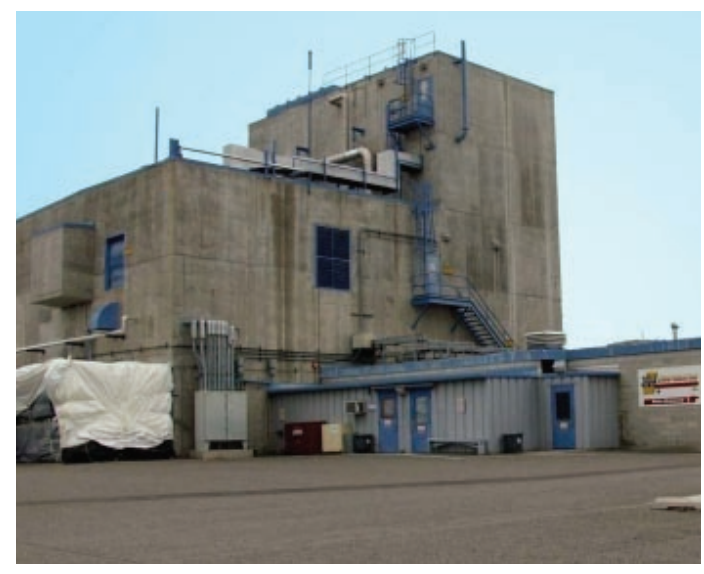

The 242-A Evaporator concentrates liquid waste from the single-shell tanks, reducing the volume transferred to the double-shell tanks.
Management of Liquid Waste. Liquid effluent is stored, treated, or disposed in facilities that comply with federal and state regulations and facility permits.

The Effluent Treatment Facility, located in the 200-East Area, treats liquid effluent to remove toxic metals, radionuclides, and ammonia, and destroy organic compounds. The treated effluent is stored in tanks, sampled and analyzed, and discharged onsite to the State-Approved Land Disposal Site. The volume of wastewater treated and disposed of in 2008 was approximately 18 million gallons.

Approximately 14 million gallons of liquid waste were stored at the Liquid Effluent Retention Facility at the end of 2008. The volume of wastewater transferred to this facility for storage in 2008 was approximately 17 million gallons.

In 2008, 73 million gallons of uncontaminated effluent were disposed of at the 200 Area Treated Effluent Disposal Facility. This facility consists of buried pipelines, three pumping stations, and two 5-acre ponds located east of the 200-East Area. The major source of this effluent was uncontaminated cooling water and steam condensate from various Hanford Site facilities.

Industrial wastewater generated throughout the Hanford Site is collected and treated in the 300 Area Treated Effluent Disposal Facility. The wastewater consists of cooling water, steam condensate, and other industrial wastewater. The volume of industrial wastewater treated and disposed of during 2008 was 42.4 million gallons.

The 242-A Evaporator in the 200-East Area concentrates diluted liquid waste from single-shell underground waste storage tanks by evaporation. This reduces the volume of liquid waste sent to the double-shell tanks for storage and reduces the potential need for more double-shell tanks. 
No waste campaigns were processed through the 242-A Evaporator in 2008.

The 242-A Evaporator completed a single cold run (raw water feed) as part of maintenance testing and personnel training. The volume of process condensate transferred to the Liquid Effluent Retention Facility for subsequent treatment in the Effluent Treatment Facility was 0.19 million gallon.

Underground Waste Storage Tanks. In 2008, 69,000 gallons of waste (including dilution or flush water used in waste retrieval activities) were pumped from single-shell tanks to the doubleshell tanks, leaving 29.8 million gallons of waste remaining in the single-shell tanks. At the end of 2008, there were 26.7 million gallons of waste in the double-shell tanks.

\section{Hanford Tank Waste Treatment and Immobili-} zation Plant. The Hanford Tank Waste Treatment and Immobilization Plant is being built on 65 acres adjacent to the 200-East Area. This plant will treat radioactive and hazardous waste pres-

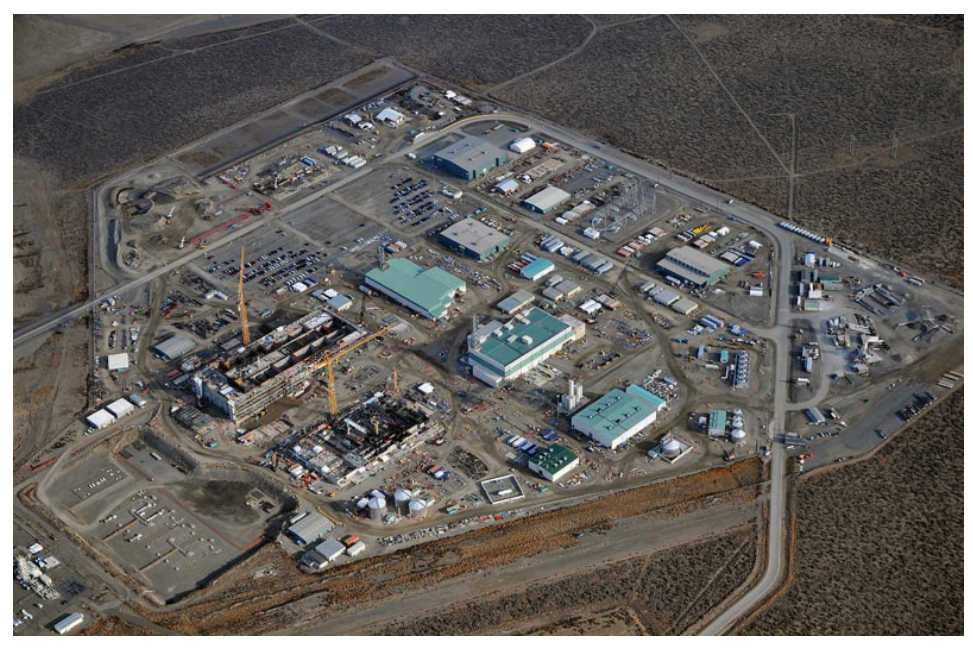

Construction on the Hanford Tank Waste Treatment and Immobilization Plant continued during 2008. facilities continued in 2008: a pretreatment facility, a high-level waste vitrification facility, a low-activity waste vitrification facility, and an analytical laboratory, as well as supporting facilities. Overall, the project was approximately $45 \%$ complete at the end of 2008 .

\section{POLLUTION PREVENTION AND WASTE MINIMIZATION}

The Pollution Prevention and Waste Minimization Program is an organized and continuing effort to reduce the quantity and toxicity of hazardous, radioactive, mixed, and sanitary waste generated at the Hanford Site.

In 2008, 1,690 tons of sanitary and hazardous wastes were recycled through site-wide programs.

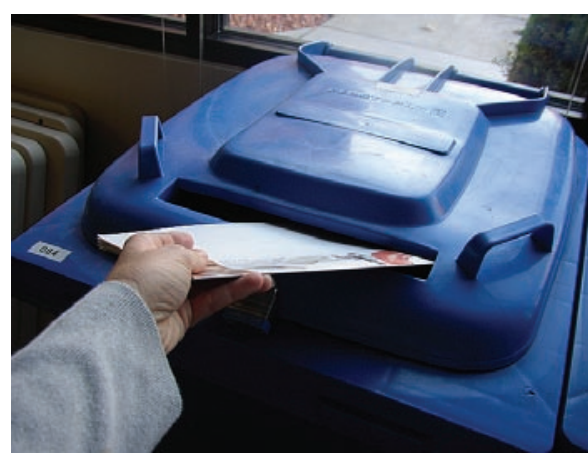

Mixed office paper and cardboard were recycled as part of the Pollution Prevention and Waste Minimization Program 


\section{ENVIRONMENTAL AND RESOURCE PROTECTION PROGRAMS}

Sediment samples are obtained semiannually from West Lake, the only naturally occurring pond on the Hanford Site. Photo courtesy of Bradley Johns.
DOE Orders require that emission, effluent, and environmental monitoring programs be conducted at the Hanford Site to verify protection of the site's environmental and cultural resources, the public, and site workers, and to comply with government regulations.

\section{AIR EMISSIONS}

Hanford Site contractors monitor airborne emissions from site facilities to assess the effectiveness of emission treatment and control systems, pollution management practices, and determine compliance with state and federal regulatory requirements. Small quantities of tritium, strontium-90, iodine-129, cesium-137, plutonium-238, plutonium-239/240, plutonium-241, and americium-241, and a few other isotopes are released in the 100, 200, 300, 400, and 600 Areas of the Hanford Site.

Non-radioactive air pollutants are emitted from power-generating and chemicalprocessing facilities. These facilities are monitored when activities are known 
to generate potential pollutants of concern, which include carbon monoxide, gaseous ammonia, lead, nitrogen oxides, particulate matter, sulfur oxides, and volatile organic compounds.

Air emissions data collected in 2008 were comparable to those collected in 2007.

\section{AMBIENT-AIR MONITORING}

Radioactive constituents in air are monitored on the Hanford Site near facilities and operations, at site-wide locations away from facilities, offsite around the perimeter of the site, and in nearby and distant communities.

Ambient-Air Monitoring Near Facilities and Operations. In 2008, ambient air was monitored at 92 locations on the Hanford Site near facilities and operations. Samplers were located primarily at or within approximately 1,640 feet of sites or facilities having the potential for, or a history of, environmental releases. Samples collected from locations at or directly adjacent to Hanford Site facilities had higher radionuclide concentrations than samples collected farther away. In general, radionuclide concentrations in most Hanford Site near-facility samples were greater than levels measured in samples collected offsite. However, radionuclide concentrations in samples collected in 2008 were at or near background levels and much less than EPA limits.
Concentrations of radioactive materials in air are monitored continuously on and off the Hanford Site.

\section{Ambient-Air Monitoring at Hanford Site-Wide and} Offsite Locations. During 2008, samples were collected at 42 continuously operating site-wide and offsite locations: 23 onsite (site-wide), 11 at site perimeter locations, 7 in nearby communities, and 1 in a distant community. Airborne particle samples were collected at each station biweekly and monitored for gross alpha and gross beta concentrations. Biweekly samples were combined into quarterly composite samples and analyzed for gamma-emitting radionuclides. Samples of atmospheric water vapor were collected every 4 weeks and analyzed for tritium at 20 locations. All air sample results showed very low radiological concentrations in 2008 and were below the EPA Clean Air Act dose standard of 10 millirem per year.

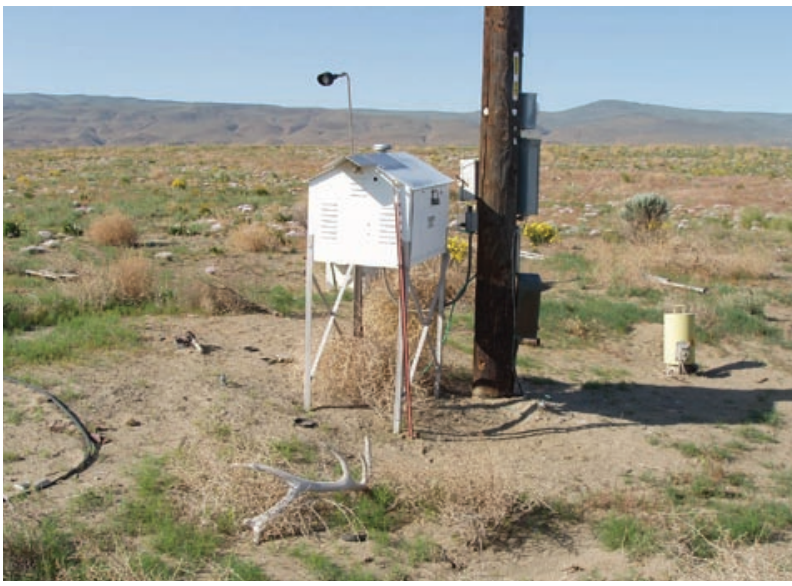

Air samplers on the Hanford Site were located primarily around major operational areas to maximize the ability to detect radiological contaminants resulting from site operations. Photo courtesy of Bradley Johns.

\section{LIQUID EFFLUENT MONITORING}

Effluent entering the environment at designated discharge points is sampled and analyzed to determine compliance with applicable Hanford Site discharge 
permits. Liquid effluent streams from Hanford Site facilities are sampled for gross alpha and gross beta concentrations, as well as for concentrations of selected radionuclides. In 2008, facilities in the 200 Areas discharged radioactive liquid effluent to the ground at a single location, the State-Approved Land Disposal Site. Non-radioactive hazardous materials in liquid effluent are monitored in the 100, 200, 300, and 400 Areas. The non-radioactive effluent is discharged to the State-Approved Land Disposal Site and to the Columbia River.

\section{SURFACE-WATER AND SEDIMENT MONITORING}

Samples of surface water and sediment on and near the Hanford Site were collected and analyzed to determine the concentrations of radiological and chemical contaminants from the Hanford Site. Surface water bodies included the Columbia River, onsite ponds, and offsite irrigation sources. Aquatic sediment was collected from the Columbia River and one onsite pond.

Water from the Columbia River. During 2008, Columbia River water samples were collected with automated samplers at fixed-location monitoring stations at Priest Rapids Dam and at the city of Richland, Washington, and analyzed for radionuclides. Samples were also taken from cross-river transects

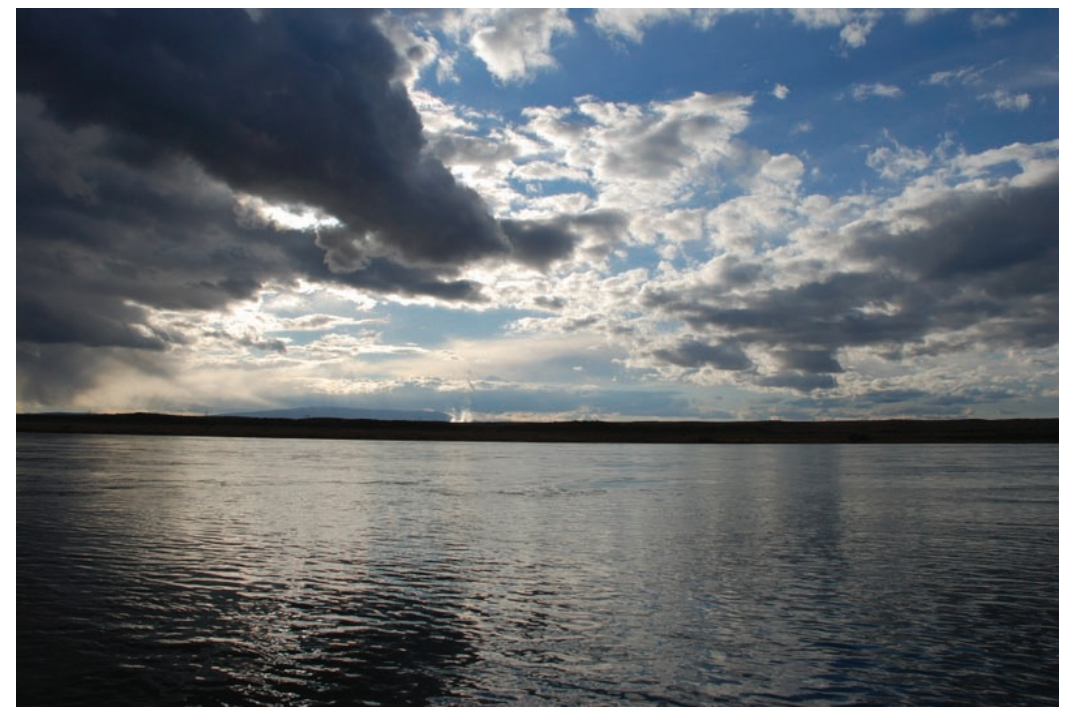

The Columbia River flows through the northern portion of the Hanford Site and forms part of the site's eastern boundary. Photo courtesy of Geoffrey McMichael. and near-shore locations near the Vernita Bridge, 100-N Area, Hanford town site, 300 Area, and the city of Richland and analyzed for both radionuclides and chemicals. Radiological constituents of interest included gamma-emitting radionuclides, tritium, strontium-90, technetium-99, uranium-234, uranium-235, uranium-238, plutonium-238, and plutonium-239/240. Gross beta and gross alpha concentrations were also monitored. Chemicals of interest included metals and anions. All radiological contaminant concentrations measured in Columbia River water at the fixed sampling locations during 2008 were less than 1/25th of the DOE effective dose equivalent standard of 100 millirem per year. Tritium, uranium-234, and uranium-238 were consistently measured in transect and near-shore samples but all measured concentrations were less than applicable Washington State ambient surfacewater quality criteria. Metals and anions were detected in Columbia River 


\section{HANFORD SITE MONITORING RESULTS FOR 2008}

\section{What Was Monitored?}

Air

Columbia River Water and Sediment

Columbia River

Shoreline Spring Water and Sediment

Food and Farm Products cherries were collected from locations upwind

Fish and Wildlife

Game animals and other animals of interest on the Hanford Site and fish from the Hanford Reach of the Columbia River were monitored. Carcass, liver, and muscle samples were analyzed to evaluate radionuclide and metals concentrations. Populations of selected fish and wildlife species were also surveyed or monitored.
Samples of milk, potatoes, tomatoes, and and downwind of the Hanford Site.

\section{The Bottom Line}

All measurements of radioactive materials in air were below recommended guidelines. In general, radionuclide concentrations near facilities were at or near Hanford Site background levels, and were much less than DOE-derived concentration guides. Some Hanford Site values were greater than concentrations measured offsite. The data also show that concentrations of certain radionuclides were higher and widely variable within different onsite operational areas.

As in past years, small amounts of radioactive materials were detected downriver from the Hanford Site. However, the amounts were far below federal and state limits. During 2008 , there was no indication of any deterioration of Columbia River water or sediment quality resulting from operations at the Hanford Site.

Measurements of radiological contaminants in samples collected at the shoreline springs were less than applicable concentration guides. Most of the 2008 chemical sample results were similar to those reported previously. Concentrations of volatile organic compounds were near or below their detection limits in all samples. Trace amounts of chlorinated organic compounds were observed at some locations. Concentrations of most metals were below Washington State ambient surface-water chronic toxicity levels.

Radionuclide concentrations measured in shoreline sediment samples were similar to concentrations measured in Columbia River sediment, with the exception of the 300 Area where uranium concentrations were above the background concentration measured in the sediments from the reservoir behind Priest Rapids Dam. Metals concentrations in all samples were also similar to concentrations measured in Hanford Reach Columbia River sediment samples.

Radionuclide concentrations in samples of food and farm products were at normal environmental levels.

Samples of carp, suckers, smallmouth bass, mule deer, and clams were collected and analyzed. Radionuclide levels in wildlife samples were well below levels that are estimated to cause adverse health effects to animals or to the people who may consume them. Most trace metal concentrations in liver samples were similar to or less than concentrations measured in background samples. Onsite wildlife samples had elevated maximum values for some trace metals. Concentrations of uranium in clam samples were highest from clams exposed to the 300 Area uranium groundwater plume.

Ninety-five routine soil samples were collected onsite near facilities and operations in 2008 to verify known radiological conditions. There were also 41 soil samples collected site-wide and at offsite locations to investigate potential contamination.

In general, radionuclide concentrations in routine samples collected from or adjacent to waste disposal facilities in 2008 were higher than concentrations measured in distant communities in previous years. There were 16 instances of radiological contamination in soil samples investigated in 2008. Of the 16,9 were cleaned up. The contamination levels at the other locations did not exceed the radiological control limits for the sites and the soil was left in place.

Vegetation

Samples of perennial vegetation were collected near Hanford Site facilities and operations in 2008 and analyzed for radiological contaminants.
Concentrations of radionuclides were elevated in vegetation samples collected near facilities and operations when compared to concentrations in samples from distant communities collected in 2004. 
transect water samples both upstream and downstream of the Hanford Site. All concentrations measured in 2008 were below regulatory limits.

Sediment from the Columbia River. During 2008, samples of the surface layer of Columbia River sediment were collected from Priest Rapids Dam,

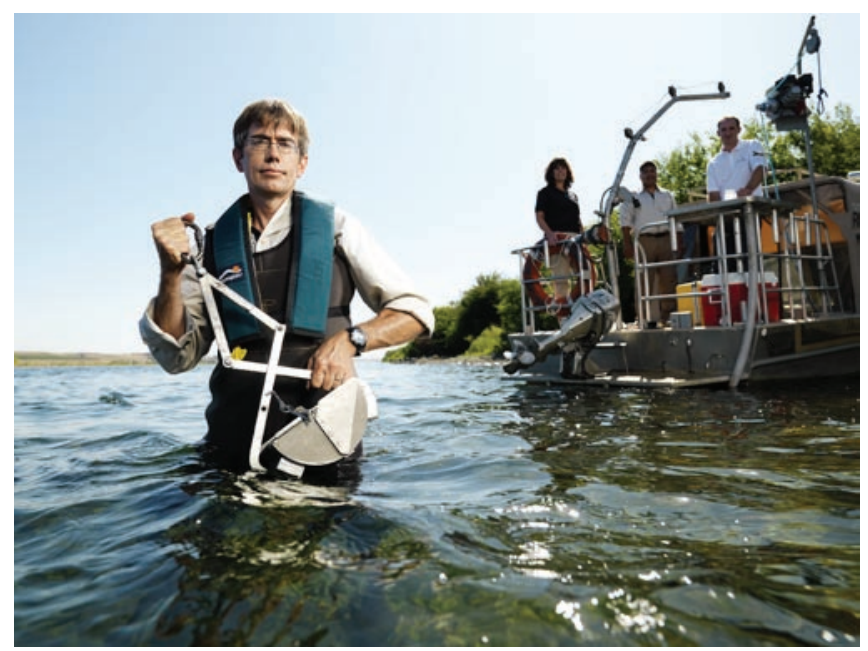
McNary Dam, and Ice Harbor Dam reservoirs; slackwater areas along the Hanford Reach; and at the city of Richland. Radionuclides consistently detected at low levels in Columbia River sediment in 2008 included natural potassium-40, cesium-137, uranium-234, uranium-235, uranium-238, plutonium-238, plutonium-239/240, and daughter products from naturally occurring radionuclides. Radionuclide concentrations observed during 2008 were similar to those reported for previous years. Detectable amounts of most metals were found in all river sediment samples. There are no Washington State freshwater sediment quality criteria for comparison to the measured metals values.

Sediment samples are routinely collected from the Columbia River and analyzed for radionuclides and chemicals.
Water and Sediment from Ponds. Two onsite ponds, West Lake and the Fast Flux Test Facility Pond, were sampled in 2008. Water samples were obtained quarterly from both ponds and sediment samples were obtained semiannually from West Lake. All water samples were analyzed for tritium and samples from the Fast Flux Test Facility Pond were also analyzed for gross alpha, gross beta, and gamma-emitting radionuclides. All radionuclide concentrations in onsite pond water samples were less than applicable DOE-derived concentration guides and Washington State ambient surface-water quality criteria. Concentrations in sediment samples were similar to concentrations measured in prior years.

Offsite Irrigation Water. In 2008, water samples were collected from an irrigation canal located east of the Columbia River downstream from the Hanford Site in the Riverview area of Pasco, and from an irrigation water supply in Benton County near the southern boundary of the Hanford Site. All radionuclide concentrations were at the same levels detected
Water samples are routinely collected from the Fast Flux Test Facility Pond and analyzed for radionuclides and chemicals. Photo courtesy of Bradley Johns. in Columbia River water obtained upstream of the Hanford Site and were below applicable DOE-derived concentration guides and Washington State ambient surface-water quality criteria. 


\section{COLUMBIA RIVER SHORELINE SPRINGS MONITORING}

Samples of Columbia River shoreline spring water and sediment were collected along the Hanford Reach and analyzed for Hanford Site-associated radiological and chemical contaminants that are present in groundwater beneath the site.

Water from Columbia River Shoreline Springs. Grab samples of shoreline spring water were obtained from numerous locations in the fall of 2008 when Columbia River flows were low. Most samples were analyzed for gammaemitting radionuclides, gross alpha, gross beta, and tritium. Samples from selected shoreline springs were analyzed for strontium-90, technetium-99, uranium-234, uranium-235, and uranium-238. Most samples were also analyzed for metals and anions, and samples from some locations were monitored for volatile organic compounds. All radiological contaminants measured in shoreline springs during 2008 were less than applicable DOE concentration guides.

In 2008, concentrations of volatile organic compounds were near or below the analytical laboratory's required detection limits. Trace amounts of chlorinated organic compounds were detected below the analytical laboratory's required detection limit in some samples from the 100-B, 100-K, 100-F, and

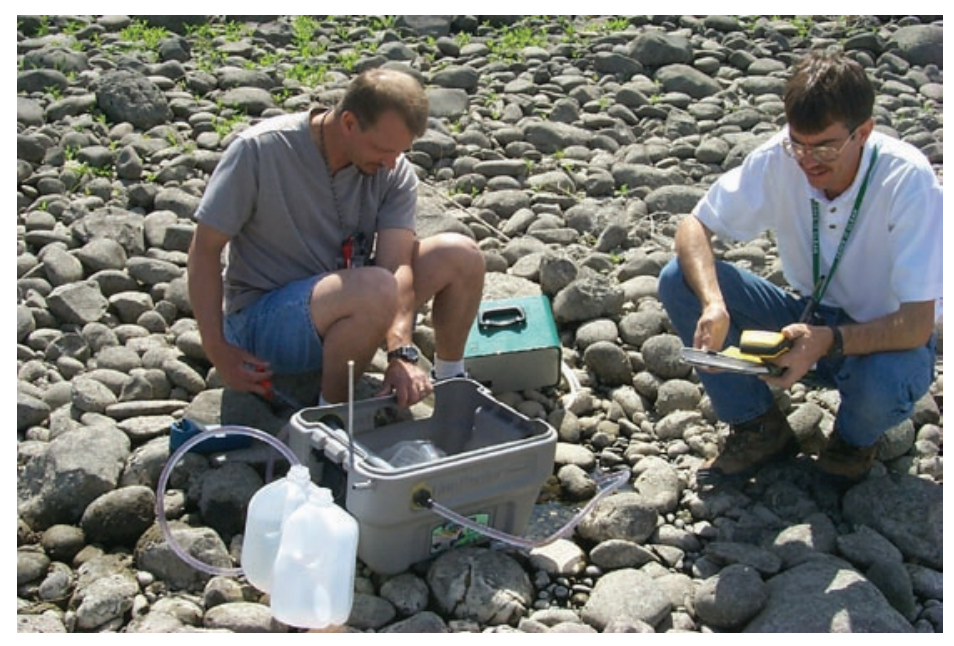

Routine monitoring of shoreline springs helps characterize the quality of groundwater discharging to the Columbia River and to assess the potential human and ecological risk associated with the spring ambient surface-water chronic toxicity levels. However, maximum concentrations of dissolved chromium in some water samples from the 100-B, 100-K, $100-\mathrm{N}, 100-\mathrm{D}, 100-\mathrm{H}$, and 100-F Areas were above the Washington State ambient surface-water chronic and acute toxicity levels. Chromium is currently being monitored through remedial investigation/feasibility studies and remediaton using pump-and-treat technology is ongoing. Arsenic, associated with historical application of arsenate on fruit orchards prior to World War II, has contributed to contamination on the Hanford Site. Concentrations of arsenic in all shoreline spring samples were below the Washington State ambient surface-water chronic toxicity level, but exceeded the EPA limit for the protection of human health for the consumption of water and organisms.

Sediment from Columbia River Shoreline Springs. Shoreline springs sediment samples were collected in the 100-B, 100-K, 100-H, and 100-F Areas, the 


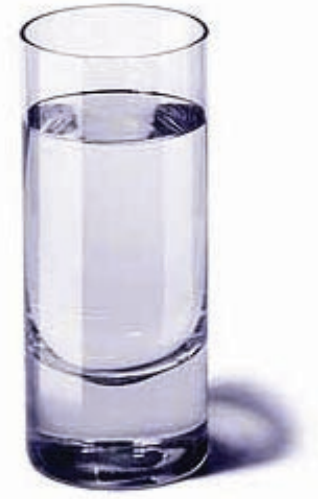

Drinking water is sampled at various locations on the Hanford Site.

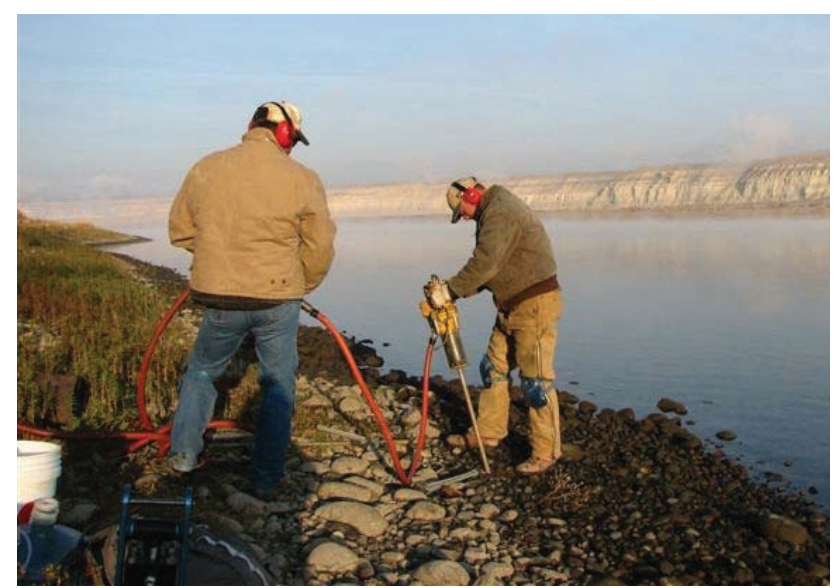

Groundwater is monitored using aquifer tubes at numerous locations along the Hanford Reach of the Columbia River.

\section{GROUNDWATER MONITORING}

300 Area, and at the Hanford town site. In 2008, radionuclide concentrations were similar to concentrations measured in Columbia River sediment, with the exception of uranium concentrations in the 300 Area, which were above the concentration measured in sediment from the reservoir behind Priest Rapids Dam, upriver from the Hanford Site. Metals concentrations in all shoreline spring samples were similar to concentrations measured in Columbia River sediment samples.

\section{RADIOLOGICAL MONITORING OF HANFORD SITE DRINKING WATER}

Samples of treated drinking water were collected monthly at facilities in the $100-\mathrm{K}, 100-\mathrm{N}, 200-$ West, and 400 Areas. Water used in the 400 Area is pumped from wells. Water treated at other locations is obtained from the Columbia River. Water samples were analyzed for gross alpha, gross beta, tritium, and strontium-90. During 2008, annual average concentrations of all monitored radionuclides in Hanford Site drinking water were below federal and state maximum allowable contaminant levels.

Liquid waste released to the ground at the Hanford Site during many years of nuclear materials production has reached the groundwater. Hazardous chemicals in the groundwater include carbon tetrachloride, chromium, and nitrate. Radioactive contaminants include tritium, strontium-90, technetium-99, iodine-129, and uranium. Currently, groundwater contaminant levels are greater than drinking water standards beneath $12 \%$ (approximately 70 square miles) of the area of the Hanford Site and are decreasing with time due to radioactive decay and contaminant dispersion. Site groundwater is not a source of public drinking water and does not significantly affect offsite drinking water sources, such as the Columbia River and city wells. However, there are possible near-shore effects where Hanford Site groundwater flows into the Columbia River. Groundwater monitoring and characterization continued in 2008, with the installation of 113 new monitoring wells, nearly 400 characterization boreholes, and 140 additional aquifer tubes on the Columbia River shoreline. Further details are available in the Hanford Site Environmental Report for Calendar Year 2008 
or the Hanford Site Groundwater Monitoring for Fiscal Year 2008, available at http://www.hanford.gov/rl/uploadfiles/GWRep08/start.htm.

\section{FOOD AND FARM PRODUCTS MONITORING}

During 2008, food and farm products including milk, potatoes, tomatoes, and cherries, were collected at places around the Hanford Site and analyzed for radiological contaminants. The concentrations of most radionuclides in food

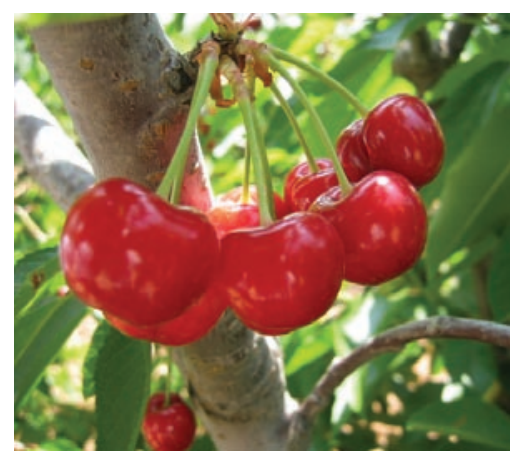

Cherries and other agricultural crops were collected during 2008. and farm product samples in 2008 were below levels that could be detected by the analytical laboratories. However, tritium and uranium-234 were detected in low levels in some samples, as was naturally occurring potassium-40, and were consistent with historical concentrations.

\section{SOIL MONITORING}

In 2008, soil samples were collected near facilities and operations at the Hanford Site to evaluate long-term trends in the environmental accumulation of radioactive materials, to detect the potential migration of contaminants, and to monitor the deposition of facility emissions. Samples were analyzed for radionuclides expected to occur in the areas sampled. In general, radionuclide concentrations in soil samples collected from or adjacent to operational areas and waste disposal facilities in 2008 were higher than the concentrations in samples collected farther away, and were higher than concentrations measured offsite in previous years. Generally, the predominant radionuclides detected were fission products in the 200 and 600 Areas and uranium in the 300 and 400 Areas.

\section{VEGETATION MONITORING}

Vegetation samples were collected on or adjacent to former waste disposal sites, and from locations downwind and near or within the boundaries of operating facilities and remedial action sites to monitor for radioactive contaminants. In general, radionuclide concentrations in vegetation samples collected from, or adjacent to, waste disposal facilities in 2008 were higher than concentrations in samples collected farther away, including concentrations measured offsite. Generally, the predominant radionuclides detected were activation and fission products in the 100-N Area, fission products in the 200 and 600 Areas, and uranium in the 300 and 400 Areas.

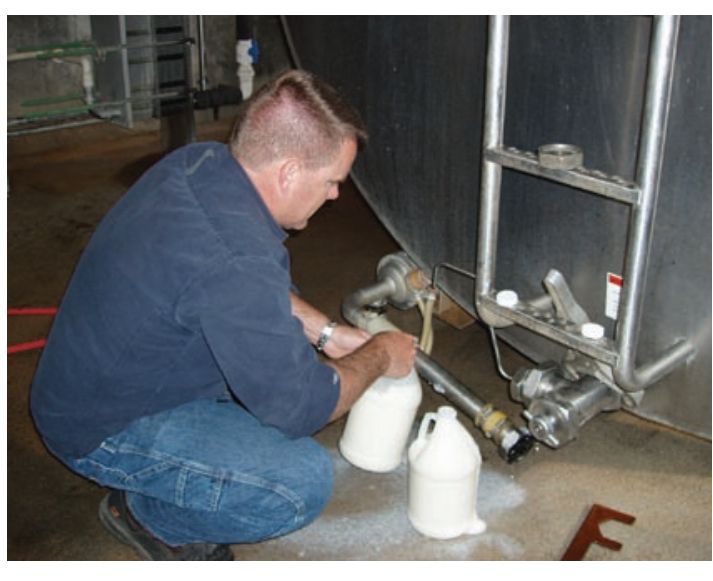

Milk samples were collected from dairies in the surrounding area. Photo courtesy of Jeffrey Ferritto.

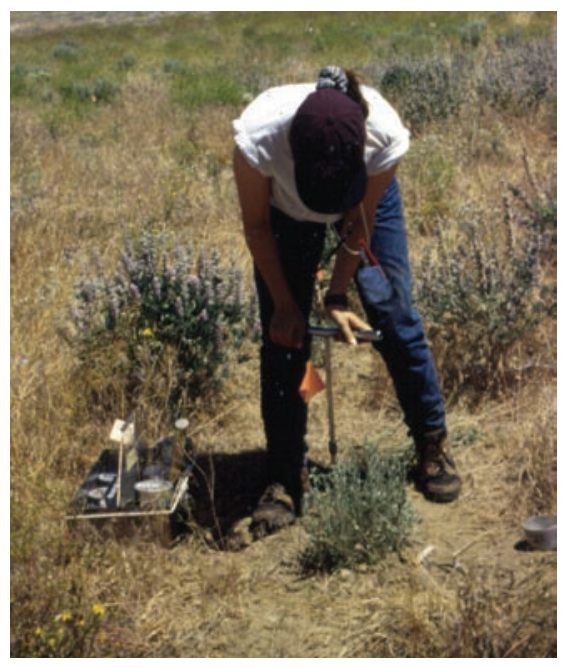

Soil samples were collected near waste disposal sites and from locations near and downwind of operating facilities and remediation sites. 


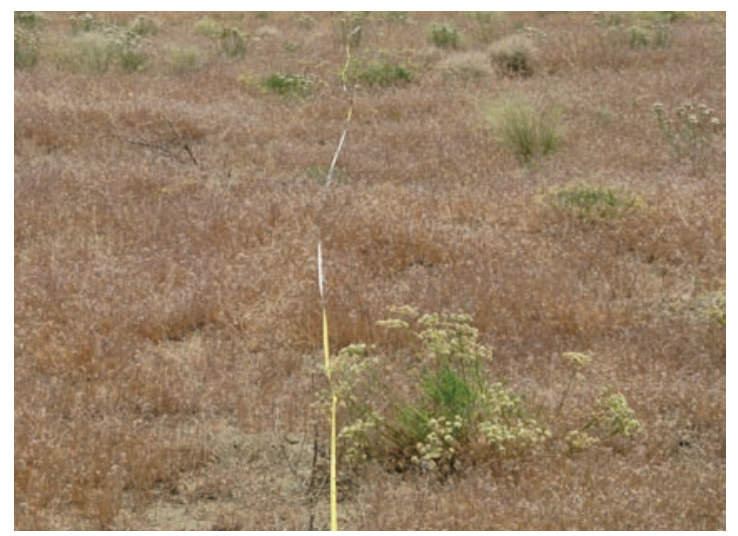

Vegetation samples are routinely collected on the Hanford Site. Photo courtesy of Kristine Hand.
During 2008, radiological contamination was found in 127 vegetation samples collected around areas of known or suspected contamination or around specific project regions on the Hanford Site. Two samples were grasses and 125 were tumbleweeds or tumbleweed fragments. None of the samples were analyzed for specific radionuclides, and all were disposed of at a licensed facility.

\section{FISH AND WILDLIFE MONITORING}

Fish and wildlife on the Hanford Site are monitored for Hanfordproduced contaminants.

In 2008, sucker, common carp, smallmouth bass, and deer were collected at locations on and around the Hanford Site. Tissue samples were analyzed for strontium-90 and gamma emitters, including cesium-137. Since the 1990s, strontium-90 and cesium-137 have been the most frequently measured radionuclides in fish and wildlife samples. Cesium-137 was below the analytical detection limit $(0.03 \mathrm{pCi} / \mathrm{g})$ in fish and deer samples in 2008. Strontium-90, which accumulates in bone tissue, generally contributes little to human dosage because it does not accumulate in edible portions. Strontium-90 was not detected in carp or sucker carcass samples

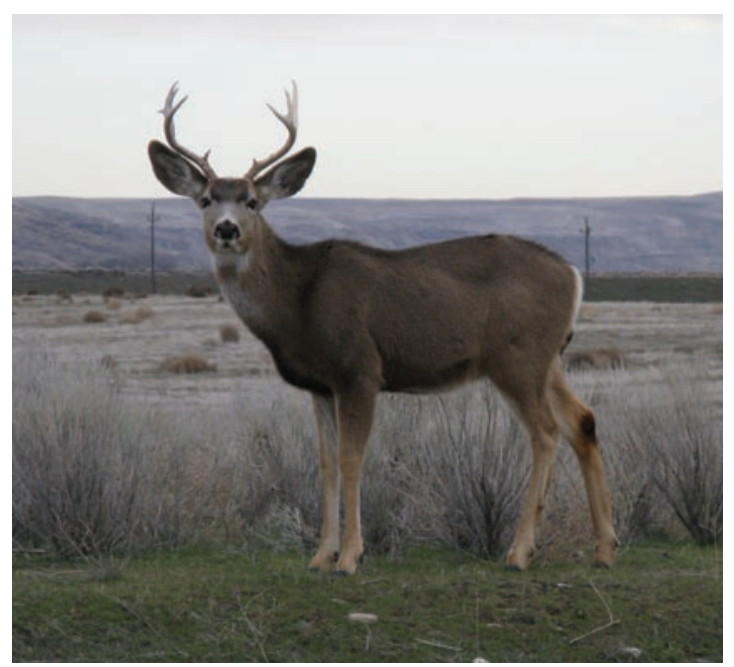

Mule deer are surveyed annually on the Hanford Site. Photo courtesy of Kristine Hand. collected onsite or at the background location, but was detected in several bass and deer samples.

Liver tissues from fish and deer were monitored for 17 trace metals. Concentrations in fish samples collected on the Hanford Site were similar to or less than those collected at the reference site in Desert Aire, Washington, with the exception of several samples collected near the 300 Area. Most trace metal concentrations in Hanford Site deer samples were similar to or less than concentrations measured from a deer collected near Olympia, Washington. Several trace metal concentrations measured in onsite deer liver samples were elevated when compared to reference samples from previous years; however, concentrations were consistent with samples collected onsite in 2004 and 2006. There are no established state or federal adverse-effect criteria for metal concentrations in fish or deer.

\section{EXTERNAL RADIATION MONITORING}

In 2008, external radiation on the Hanford Site was monitored onsite in relative close proximity to known, suspected, or potential radiation sources. A thermoluminescent dosimeter system is used to measure external radiation 
at the Hanford Site. Additionally, radiation surveys were conducted at some locations using portable instruments to monitor and detect contamination, providing a screening for external radiation fields.

Thermoluminescent Dosimeters. During the year, external radiation levels can vary from $15 \%$ to $25 \%$ at any location because of changes in soil moisture and snow cover, which can reduce or attenuate natural radiation intensity. During 2008, external radiation fields were monitored with thermoluminescent dosimeters at 124 locations near onsite facilities and operations. Measured radiation levels in 2008 were similar to or lower than levels measured in 2007.

Radiation Surveys. In 2008, 473 radiation surveys were conducted at and around active and inactive waste disposal sites. During 2008, the Hanford Site

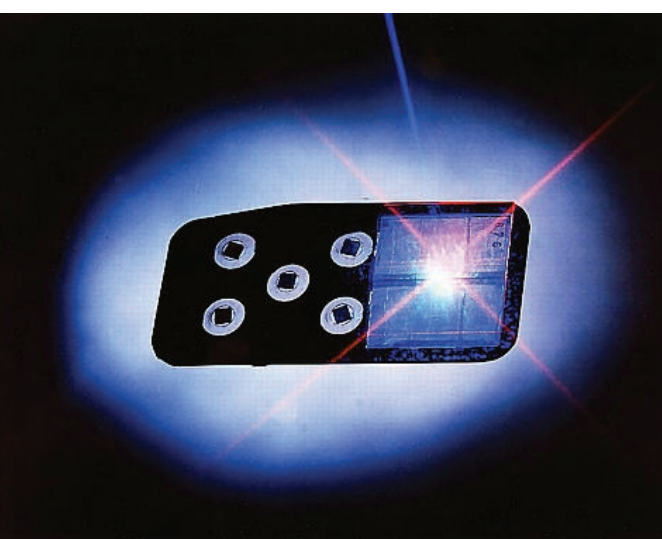

Thermoluminescent dosimeters are used to measure external radiation at the Hanford Site. had approximately 8,853 acres of outdoor contaminated areas of all types and approximately 1,443 acres that contained underground radioactive materials, not including active facilities. No new areas of significant size were discovered during 2008 and 22 acres that had been previously posted as contaminated or as areas containing radioactive materials were mediated and interim-closed.

\section{POTENTIAL RADIOLOGICAL DOSES FROM 2008 HANFORD SITE OPERATIONS}

During 2008, potential radiological doses to the public and biota from Hanford Site operations were evaluated to determine compliance with pertinent regulations and limits. Doses were assessed in terms of 1 ) total dose (multiple pathways) to the hypothetical, maximally exposed individual at an offsite location; 2) average dose to the collective population living within 50 miles of Hanford Site operating areas; 3) dose for air pathways using EPA methods; 4) dose to workers on the site consuming drinking water; 5) doses from non-DOE industrial sources on and near the Hanford Site; and 6) absorbed dose received by animals exposed to contaminants released to the Columbia River and in onsite surface water bodies. All doses from Hanford Site activities in 2008 were lower that EPA and DOE standards.

\section{NATURAL RESOURCES}

Plant populations are routinely surveyed on the Hanford Site. Rare or protected plant species are monitored and contaminated or unwanted vegetation on the site is controlled.

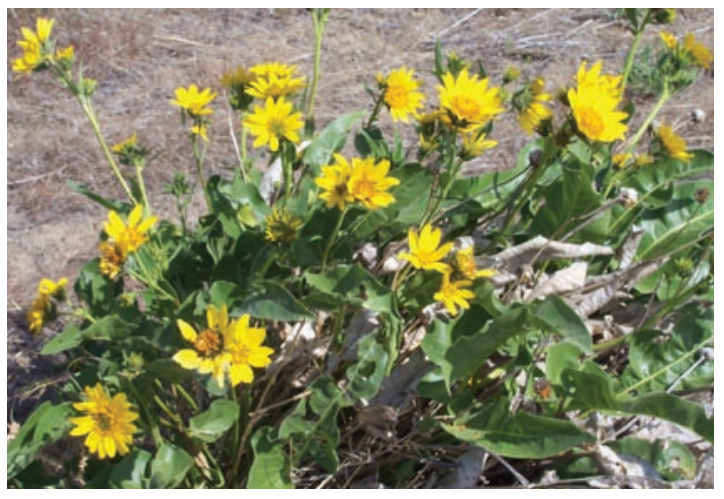

Carey's balsamroot is found on the Hanford Site. Photo courtesy of Kristine Hand. 


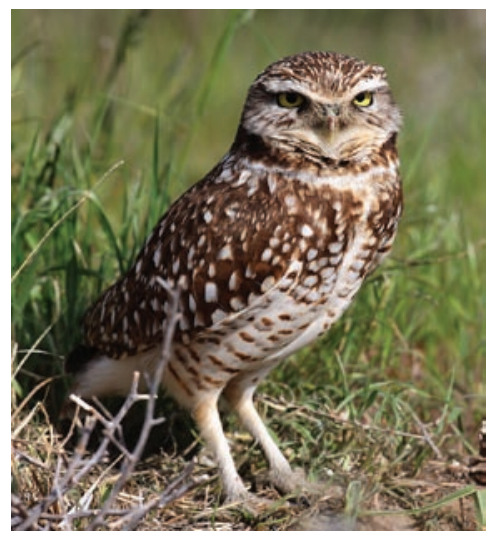

Burrowing owls, a Washington State candidate species and federal species of concern, were monitored on the Hanford Site during 2008. Photo courtesy of Mike Guthrie.

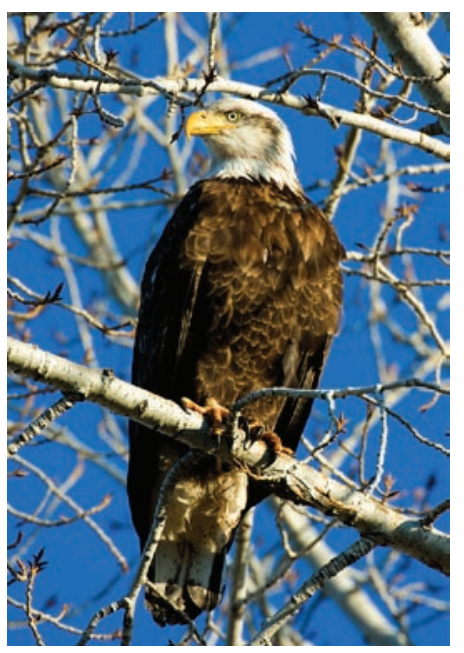

Eagles were observed during two surveys on the Hanford Site. Photo courtesy of Mike Guthrie.

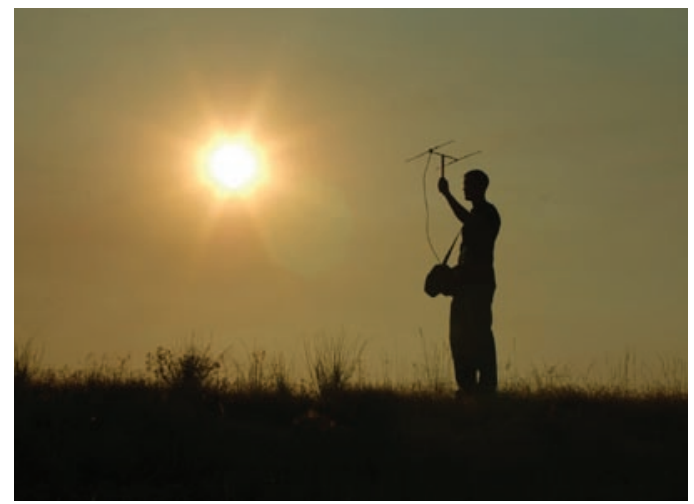

Radio telemetry was used to monitor Woodhouse's toads in 2008
Plant Communities and Population Surveys. Plant populations monitored on the Hanford Site include species listed by Washington State as endangered, threatened, or sensitive, and species listed as review group 1. Monitoring data are used to develop baseline information and to monitor for changes resulting from Hanford Site operations. Surveys for rare annual species were conducted in 2008 as part of annual compliance review activities. More than 100 plants listed as endangered, threatened, sensitive, or on the review or watch list are found on the Hanford Site.

Vegetation Control Activities. Vegetation control on the Hanford Site includes cleaning up contaminated plants that can be a threat to site workers or the public, controlling or preventing the growth or re-growth of plants in contaminated or potentially contaminated areas on the site, and monitoring and removing the 10 high-priority noxious plant species.

Wildlife Populations Surveys. Four fish and wildlife species on the Hanford Site are surveyed annually: fall Chinook salmon, steelhead, bald eagles, and mule deer. The number of fall Chinook salmon spawning nests (redds) in the Hanford Reach is estimated by aerial surveys. The peak redd count in the fall of 2008 was estimated at 5,588, higher than the 2007 count of 4,018 and below the previous 5 -year average of 7,206. Two aerial surveys were conducted to identify possible steelhead spawning areas; none were found.

Thirty-four eagles (18 adults and 16 juveniles) were observed during two surveys along the Hanford Reach from Vernita Bridge downstream to the city of Richland in January and February 2009.

Roadside surveys were conducted for mule deer on the Hanford Site to assess age and sex ratios and the frequency of testicular atrophy in males. Testicular atrophy has been associated with an unusually large number of older deer residing on the Hanford Site. In 2008, testicular atrophy was observed in $1.6 \%$ of the deer in the northern region of the Hanford Site and $5.7 \%$ of the deer in the southern region. A combined total of 566 deer observations were made over 5 repeated surveys during November 2008 to January 2009, which could include multiple observations of the same animals.

Habitat and Species Characterizations. Ecological monitoring on the Hanford Site includes the characterization of breeding locations, habitat use, and distribution of key wildlife species. In 2008, characterization studies focused on the Woodhouse's toad and the burrowing owl, a Washington state candidate species and federal species of concern in this region. Toads were monitored using radio telemetry and found predominantly within 656 feet of the Columbia River or the high-water channel of the 100-F Slough. Burrowing owl distributions and nesting habitats were evaluated; 53 nests have been documented on the Hanford Site. 
Control of Pests and Contaminated Biota. Animals (including insects) must be controlled when they become a nuisance, potential health problem, or are contaminated with radioactivity. Biological control personnel responded to approximately 33,000 animal control requests from Hanford Site employees in 2008. There were 33 contaminated animals or animal-related materials discovered in 2008 .

\section{CULTURAL AND HISTORIC RESOURCES}

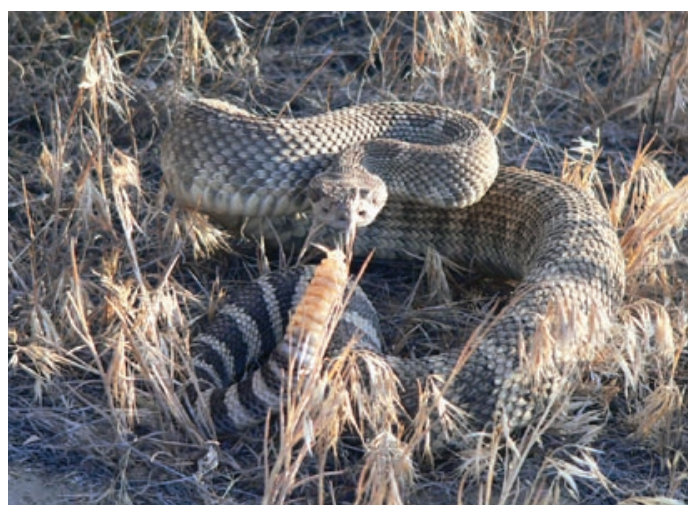

Rattlesnakes are observed during the summer on the Hanford Site.

$\mathrm{DOE}$ is responsible for managing and protecting the Hanford Site's cultural and historic resources. The Hanford Cultural and Historic Resources Program assists DOE in managing cultural and historic resources responsibly and in accordance with applicable regulatory requirements.

Cultural resources reviews are required before a federally funded, federally assisted, or federally licensed ground disturbance or building alteration/ demolition project can occur. Cultural resource reviews identify properties within the proposed

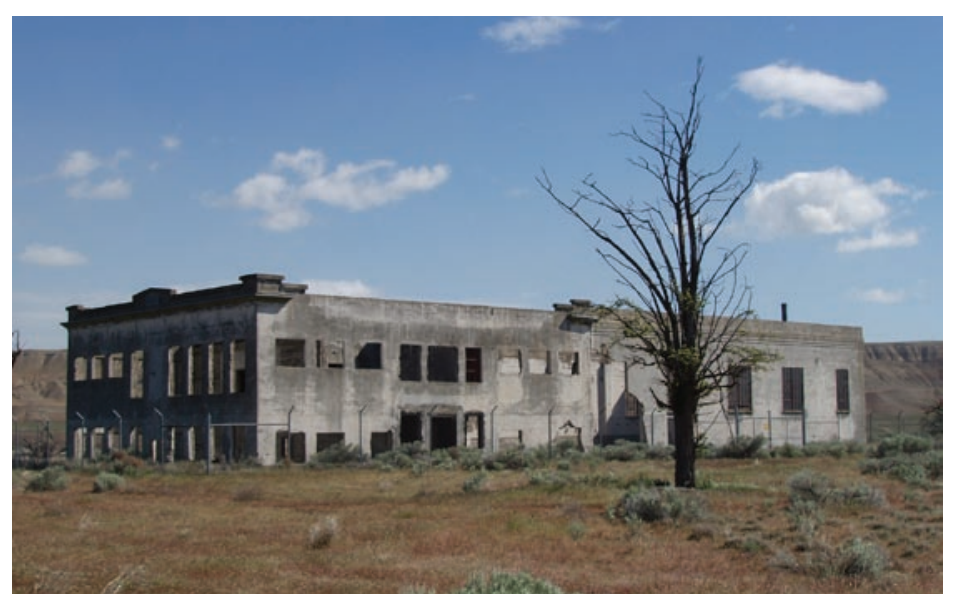
project area that may be eligible for, or listed in, the National Register of Historic Places, and evaluate the project's potential to affect any such property. During 2008, 113 cultural resource reviews were requested by Hanford Site contractors.

The Hanford Site conducts a monitoring program to assess the effects of weathering and erosion or unauthorized excavation and artifact collection of the site's cultural resources. Activities include onsite inspections of important sites. In 2008, 45 sites were visited and minor impacts from recreation, natural erosion, and animal activity were documented.

Hanford High School, one of the remaining buildings at the old Hanford town site, is eligible for listing in the National Register of Historic Places. Photo courtesy of Bradley Johns.

Meteorological

measurements are

taken to support

Hanford Site emergency

\section{CLIMATE AND METEOROLOGY}

preparedness and

response, site

Meteorological measurements support Hanford Site emergency preparedness, atmospheric dispersion calculations, worker safety, cleanup planning and performance, and waste management operations. Activities include weather forecasting and maintaining and distributing climatological data.

operations, and atmospheric dispersion calculations for dose 


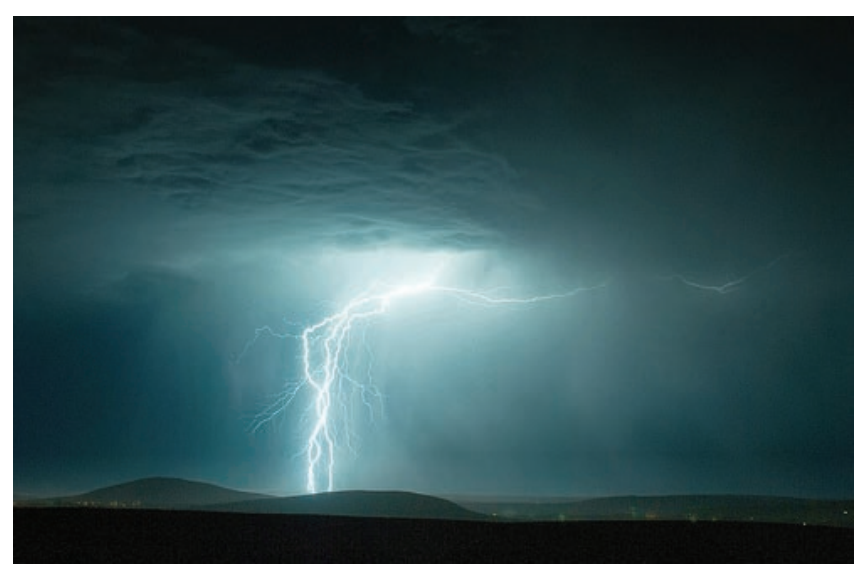

Lightning strikes often accompany severe thunderstorms occasionally starting wildfires. Photo courtesy of Scott Butner.
The calendar year 2008 average temperature and precipitation totals were below normal. The average temperature for 2008 was $52.4^{\circ} \mathrm{F}$, which was $1.2^{\circ} \mathrm{F}$ below normal $\left(53.6^{\circ} \mathrm{F}\right)$. Five months during 2008 were warmer than normal and seven months were cooler than normal.

Precipitation during 2008 totaled 5.49 inches, which is $79 \%$ of normal (6.98 inches). Snowfall for 2008 totaled 30.6 inches, compared to normal snowfall of 15.4 inches.

The average wind speed during 2008 was 8.1 miles per hour, which was 0.5 mile per hour above normal. The peak gust for the year was 59 miles per hour on February 7, 2008.

Two dust storms were recorded at the Hanford Meteorology Station during 2008 , less than the five per year average for the entire period of record (1945-2008).

\section{QUALITY ASSURANCE}

Comprehensive quality assurance programs, which include various quality control practices and methods to verify data, are maintained by monitoring and surveillance projects to assure data quality. The programs are implemented through quality assurance plans designed to meet requirements of the American National Standards Institute/American Society of Mechanical Engineers and DOE Orders. Quality assurance plans are maintained for all activities, and auditors verify conformance.

Samples are collected and analyzed according to documented standard procedures. Analytical data quality was verified by a continuing program of internal laboratory quality control, participation in interlaboratory crosschecks, replicate sampling and analysis, submittal of blind standard samples and blanks, and splitting samples with other laboratories. 

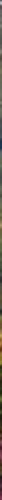

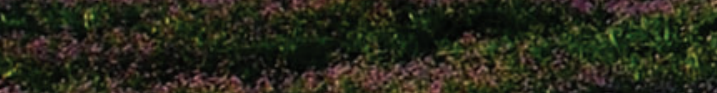

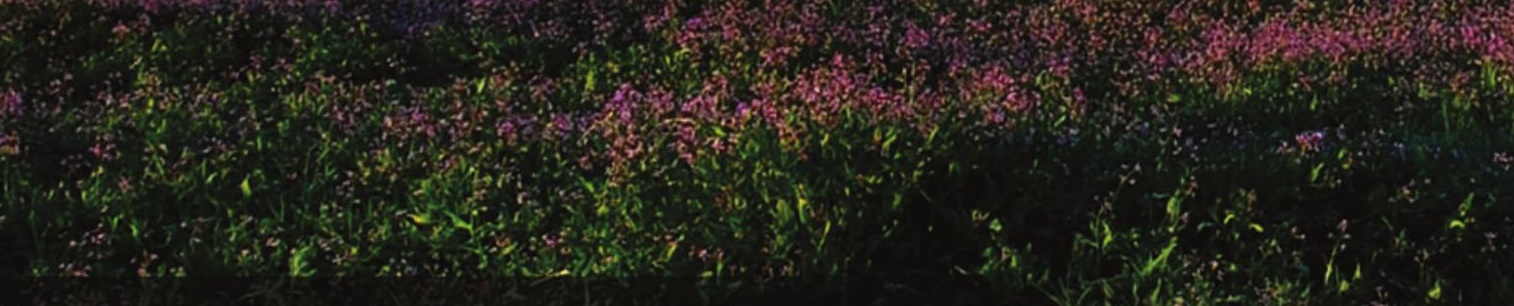

Prepared for the U.S. Department of Energy under Contract DE-AC05-76RL01830 by

\title{
Pacific Northwest
}

\author{
NATIONAL LABORATORY
}

Proudly Operated by Battelle Since 1965 